\title{
5 The Homoscleromorph Sponge, Oscarella lobularis
}

\author{
Emmanuelle Renard, Caroline Rocher, Alexander Ereskovsky \\ and Carole Borchiellini
}

\section{CONTENTS}

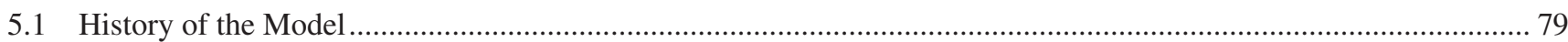

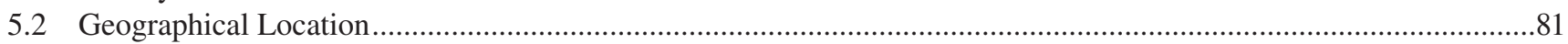

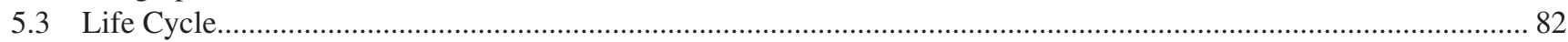

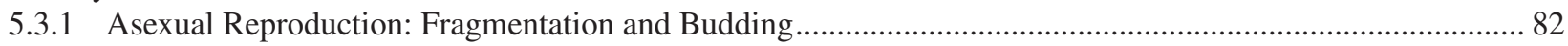

5.3.2 Sexual Reproduction, Gametogenesis and Indirect Development............................................................... 82

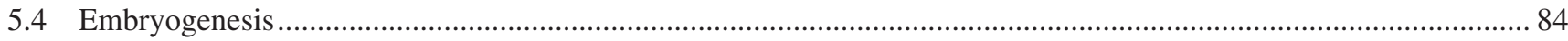

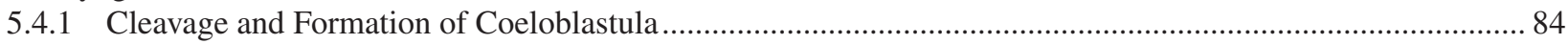

5.4.2 Morphogenesis of the Cinctoblastula Larva and Larval Metamorphosis ........................................................ 85

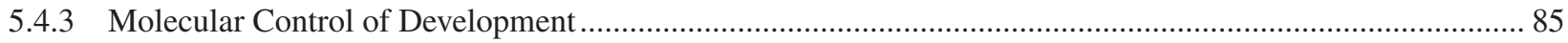

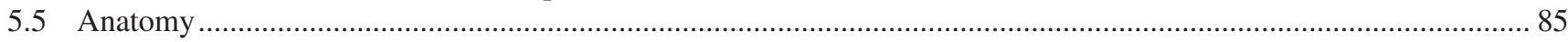

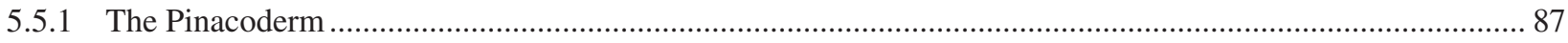

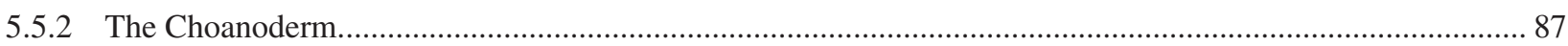

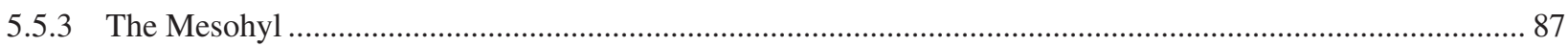

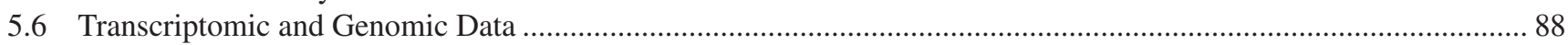

5.7 Functional Approaches: Tools for Molecular and Cellular Analyses....................................................................... 89

5.7.1 Developmental and Non-Developmental Morphogenetic Contexts Accessible ............................................. 89

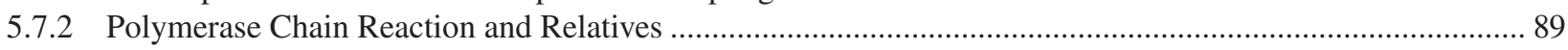

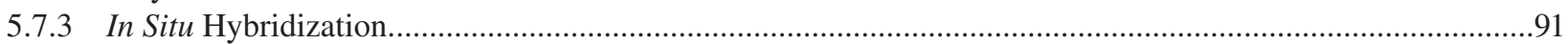

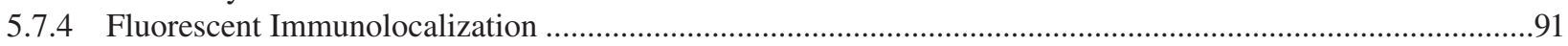

5.7.5 Cell Viability, Cell Apoptosis and Cell Proliferation Assays........................................................................91

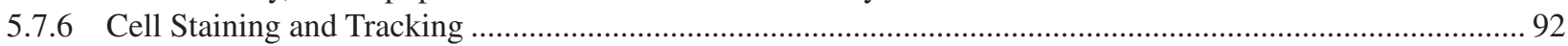

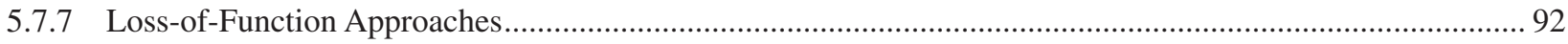

5.8 Challenging Questions Both in Academic and Applied Research ......................................................................92

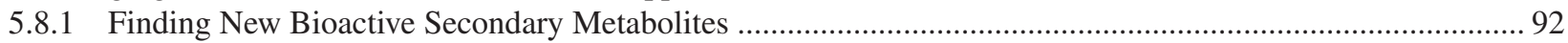

5.8.2 Understanding Host-Symbiont Interactions ......................................................................................... 93

5.8.3 Deciphering the Origin and Evolution of Metazoan Epithelia .................................................................. 93

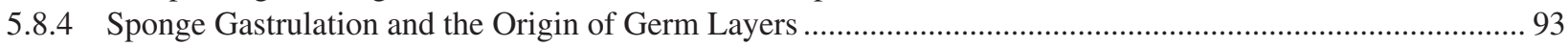

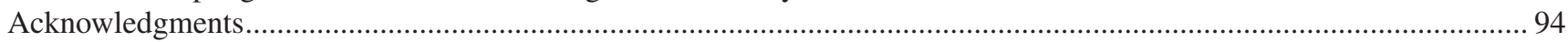

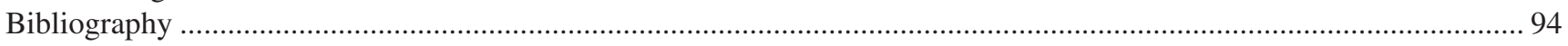

\subsection{HISTORY OF THE MODEL}

Oscarella lobularis (Schmidt 1862) was first described as Halisarca lobularis Schmidt 1862 (Schmidt 1862). Later Oscarella lobularis became the type species of the genus Oscarella Vosmaer, 1884 (Vosmaer 1884), genus, classified until 2012 (Gazave et al. 2012) within the class Demospongiae, subclass Tetractinellida, due to the shared presence of siliceous tetractinal-like calthrops spicules (Levi 1956). Despite its reported cosmopolitan distribution (uncommon in sponges because of the low dispersal capacity of most sponge larvae) and the observation of a large variety of colors (Figure 5.1c),
O. lobularis was long considered the only species of the genus Oscarella. Accordingly, all species of the Oscarella genus reported between 1930 and 1990 were probably wrongly assigned to O. lobularis (Lage et al. 2018; Pérez and Ruiz 2018).

The cosmopolitan status of Oscarella lobularis began to be questioned in 1992. Several color morphs assigned to the species $O$. lobularis (Schmidt 1862) living in sympatry in the west Mediterranean area were compared for the first time using a combination of characters: morphological characters, cytological characters and electric mobility of 12 protein markers. This study evidenced the presence of two 
distinct species. The morphs with soft consistency were then referred to $O$. lobularis, while those with cartilaginous tissues were renamed as $O$. tuberculata (Boury-Esnault et al. 1992). The lack of a mineral skeleton (spicules) in the genus Oscarella was probably in part at the origin of species misidentification, because spicules were at that time commonly used in sponge systematics (Boury-Esnault et al. 1992). Since then, the development of multi-marker approaches (genetic, chemical, cytological, embryological characters) in conjunction with the effort deployed to explore more habitats have allowed a significant improvement in our knowledge of Oscarella species diversity (Bergquist and Kelly 2004; Ereskovsky 2006; Ereskovsky et al. 2009a; Ereskovsky et al. 2017b; Gazave et al. 2013; Muricy and Pearse 2004; Muricy et al. 1996; Pérez and Ruiz 2018; Pérez et al. 2011). There are so far 21 described species in the genus Oscarella (Table 5.1); this represents about $16 \%$ of the diversity of the Homoscleromorpha lineage (Van Soest et al. 2021).

Another major revolution in the taxonomic history of $O$. lobularis was the rise of Homoscleromorpha (previously considered a family, suborder or subclass within Demospongiae; Lévi 1973) to an upper taxonomic level. Different studies showed that Homoscleromorpha represents a fourth distinct class among Porifera (Borchiellini et al. 2004; Feuda et al. 2017; Francis and Canfield 2020; Gazave et al. 2012; Hill et al. 2013; Philippe et al. 2009; Pick et al. 2010; Pisani et al. 2015; Redmond et al. 2013; Simion et al. 2017; Thacker et al. 2013; Whelan et al. 2017; Wörheide et al. 2012) (Figure 5.1a). Homoscleromorpha is the smallest sponge class of Porifera, with only 130 exclusively marine valid species (Van Soest et al. 2021). This class is split into two families, Plakinidae Schulze, 1880, and Oscarellidae Lendenfeld, 1887 (Gazave et al. 2012) (Figure 5.1b). Oscarella lobularis belongs to the family Oscarellidae, a family defined by no skeleton; a variable degree of ectosome development; sylleibid-like or leuconoid organization of the aquiferous system, with eurypylous or diplodal choanocyte chambers; and the presence of the mitochondrial tatC gene (Gazave et al. 2010; Gazave et al. 2013; Wang and Lavrov 2007) (Figure 5.1b).

Therefore, the definition of Homoscleromorpha as a class, along with the three traditional ones Demospongiae, Hexactinellida and Calcarea (Brusca et al. 2016), shed light on homoscleromorph sponge species and evidenced the usefulness of studying and comparing these species to trace back character evolution during Poriferan evolutionary history. In accordance with the growing awareness in the evo-devo community of the need to develop studies on nonbilaterian and non-conventional animal models (Adamska

\section{TABLE 5.1}

\section{List of Oscarella Species}

\begin{tabular}{|c|c|c|}
\hline Rank & Name & Original Description \\
\hline Class & Homoscleromorpha & Bergquist (1978) \\
\hline Order & Homosclerophorida & Dendy (1905) \\
\hline Family & Oscarellidae & Lendenfeld (1887) \\
\hline Genus & Oscarella & Vosmaer (1884) \\
\hline \multirow[t]{21}{*}{ Species } & Oscarella balibaloi & Pérez et al. (2011) \\
\hline & Oscarella bergenensis & Gazave et al. (2013) \\
\hline & Oscarella carmela & Muricy and Pearse (2004) \\
\hline & Oscarella cruenta & Carter (1876) \\
\hline & Oscarella filipoi & Pérez and Ruiz (2018) \\
\hline & Oscarella imperialis & Muricy et al. (1996) \\
\hline & Oscarella jarrei & Gazave et al. (2013) \\
\hline & Oscarella kamchatkensis & Ereskovsky et al. (2009a) \\
\hline & Oscarella lobularis & Schmidt (1862) \\
\hline & Oscarella membranacea & Hentschel (1909) \\
\hline & Oscarella microlobata & Muricy et al. (1996) \\
\hline & Oscarella nicolae & Gazave et al. (2013) \\
\hline & Oscarella nigraviolacea & Bergquist and Kelly (2004) \\
\hline & Oscarella ochreacea & Muricy and Pearse (2004) \\
\hline & Oscarella pearsei & Ereskovsky et al. (2017b) \\
\hline & Oscarella rubra & Hanitsch (1890) \\
\hline & Oscarella stillans & Bergquist and Kelly (2004) \\
\hline & Oscarella tenuis & Hentschel (1909) \\
\hline & Oscarella tuberculata & Schmidt (1868) \\
\hline & Oscarella viridis & Muricy et al. (1996) \\
\hline & Oscarella zoranja & Pérez and Ruiz (2018) \\
\hline
\end{tabular}

\section{Remarks}

diagnosis in: Gazave et al. (2012) diagnosis in: Gazave et al. (2012) diagnosis in: Gazave et al. (2013)

accepted as Pseudocorticium jarrei Boury-Esnault et al. (1992)

accepted as Aplysilla rubra (Hanitsch 1890)

\section{Geographical Location \\ Cosmopolitan \\ Cosmopolitan \\ Cosmopolitan \\ Cosmopolitan \\ Western Mediterranean \\ Southern Norway \\ Northern California \\ South European Atlantic Shelf \\ Eastern Caribbean \\ Western Mediterranean \\ Western Mediterranean}

Kamchatka Shelf and Coast Mediterranean

South West Australia

Western Mediterranean

Southern Norway East African

North east Pacific

Northern California

Celtic seas North Borneo

South West Australia

Mediterranean

Western Mediterranean

Eastern Caribbean 

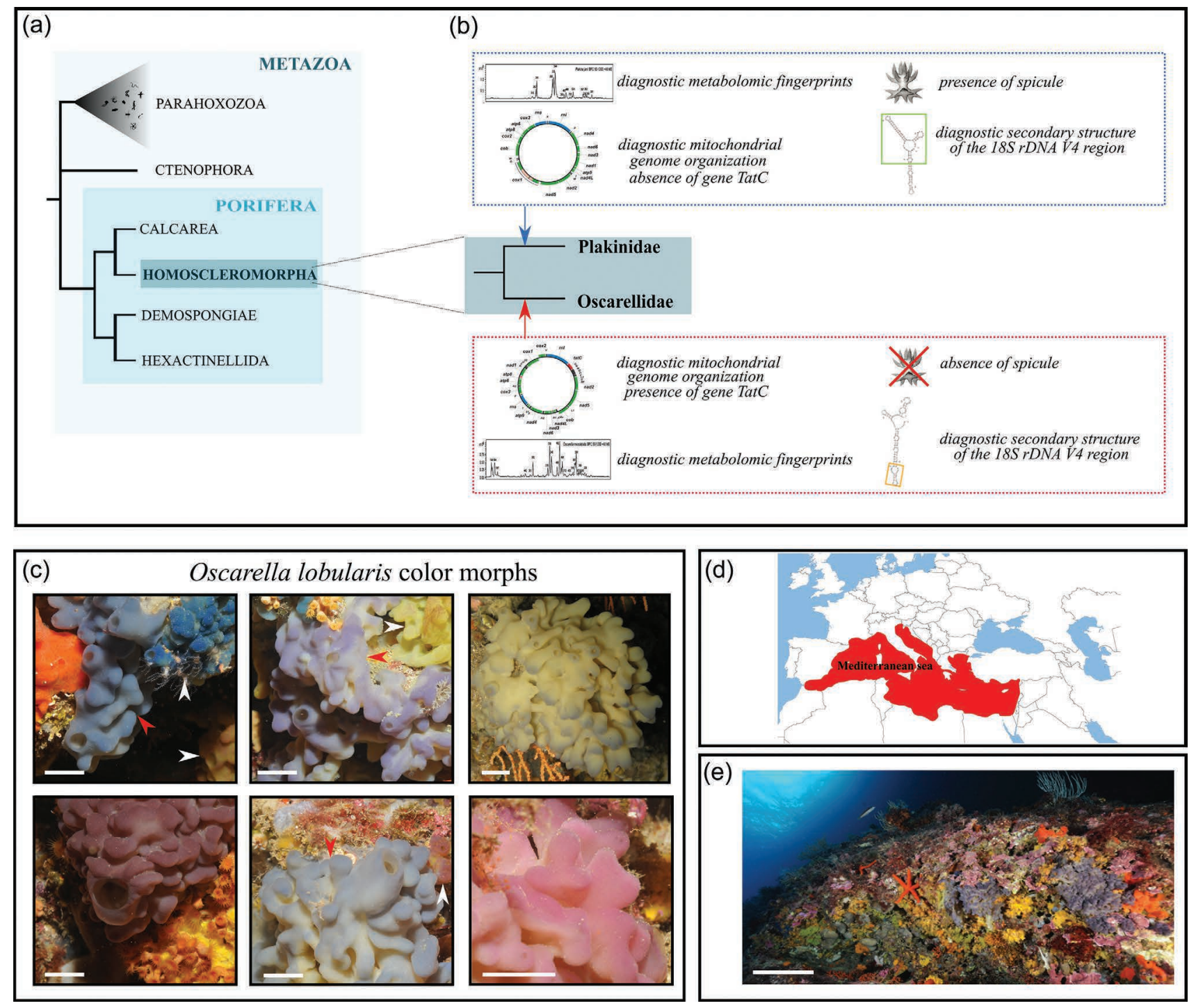

FIGURE 5.1 (a) The phylogenetic positions between Porifera and all other Metazoa and between Homoscleromorpha (to which Oscarella lobularis pertains) and other Poriferan classes. (b) The class Homoscleromorpha is split into Oscarellidae (to which Oscarella lobularis belongs) and Plakinidae, clearly distinguished by metabolomic, genetic and anatomical synapomorphies. (c) Oscarella lobularis harbors a high color polymorphism from yellowish to dark purple or blue; the color is unrelated to individual microbial community. Oscarella lobularis (red arrows) often lives in sympatry with other Oscarella species (white arrows), in particular its sister-species $O$. tuberculata. Scale bars represent $1 \mathrm{~cm}$; photo credit: Dorian Guillemain. (d) Oscarella lobularis is now considered to have a geographic distribution restricted to the Mediterranean Sea. (e) Oscarella lobularis very often inhabits the Coralligenous habitat. Scale bar: $20 \mathrm{~cm}$; photo credit: Frederic Zuberer. ([a] Borchiellini et al. 2004; Feuda et al. 2017; Francis and Canfield 2020; Gazave et al. 2012; Hill et al. 2013; Philippe et al. 2009; Pick et al. 2010; Pisani et al. 2015; Redmond et al. 2013; Simion et al. 2017; Thacker et al. 2013; Whelan et al. 2017; Wörheide et al. 2012; [b] Boury-Esnault et al. 2013; Gazave et al. 2010; Gazave et al. 2013; Ivanišević et al. 2011; [c] Gazave et al. 2012; Gloeckner et al. 2013; [d] Van Soest et al. 2021; [e] Bertolino et al. 2013.)

2016; Adamska et al. 2011; Colgren and Nichols 2019; Jenner and Wills 2007; Lanna 2015; Love and Yoshida 2019), Oscarella lobularis in Europe and O. pearsei (Ereskovsky et al. 2017b) in America began to be studied from an evo-devo perspective (Fierro-Constaín et al. 2017; Gazave et al. 2008; Gazave et al. 2009; Lapébie et al. 2009; Miller et al. 2018; Mitchell and Nichols 2019; Nichols et al. 2006; Nichols et al. 2012; Schenkelaars et al. 2015; Schenkelaars et al. 2016a).

\subsection{GEOGRAPHICAL LOCATION}

Homoscleromorpha, including species of the genus Oscarella, have a worldwide distribution, with three oceanic regions representing current hotspots of diversity (or hotspots of descriptions of new species): the Mediterranean Sea (Ereskovsky et al. 2009b; Lage et al. 2018), the tropical western Atlantic Ocean (Domingos et al. 2016; Ereskovsky et al. 2014; Pérez and Ruiz 2018; Ruiz et al. 2017; Vicente 
et al. 2016) and the Pacific Ocean (Bergquist and Kelly 2004; Ereskovsky 2006; Ereskovsky et al. 2009a; Lage et al. 2018; Muricy and Pearse 2004). In contrast, O. lobularis is found from the Gibraltar Strait to the eastern Mediterranean, including the Adriatic Sea, and is therefore presently considered a species endemic to the Mediterranean Sea (Ereskovsky et al. 2009b) (Figure 5.1d). Indeed, the other locations previously reported (for instance, Madagascar or the Manche Sea) were shown to be misidentifications (Lévi and Porte 1962; Muricy and Pearse 2004; Van Soest et al. 2007).

In Mediterranean ecosystems, sponges represent one of the main animal groups: a study by Coll et al. (2010) estimated that Porifera represent about $12.4 \%$ of the animal diversity (a proportion in the same range as that of vertebrate species diversity). Among the 681 poriferan species present in the Mediterranean (Coll et al. 2010), only 25 species (about 3\% of the sponge species diversity) belong to Homoscleromorpha (Lage et al. 2019). Among them, $O$. lobularis is one of the most common and abundant species in some places (Ereskovsky et al. 2009b).

O. lobularis is mainly located in shallow waters from 4 to $35 \mathrm{~m}$ and in sciaphilic hard substratum communities including semi-dark and dark submarine caves (Ereskovsky et al. 2009b). In particular, O. lobularis is one of the 273 sponge species involved in coralligenous accretion (Bertolino et al. 2013) (Figure 5.1e). The infra- and circalittoral coralligenous habitats (first defined by Marion 1883) are now recognized as one of the main Mediterranean biocoenoses. In these habitats, unlike bioeroding Clionidae, O. lobularis usually grows on top of other sponges or on cnidarians (such as sea fans), bryozoans, annelid tubes, mollusk shells or lithophyllum; it is therefore usually considered an efficient space competitor (Garrabou and Zabala 2001).

\subsection{LIFE CYCLE}

Like many other sponges whose life cycles have been described (Ereskovsky 2010; Fell 1993), Oscarella lobularis is capable of both sexual and asexual reproduction. These types of reproduction alternate naturally during the same year (Figure 5.2).

\subsubsection{Asexual Reproduction: Fragmentation AND BUDDING}

The timing and process of asexual reproduction in Oscarella lobularis have been described in several complementary studies (Ereskovsky 2010; Ereskovsky and Tokina 2007; Fierro-Constain 2016; Rocher et al. 2020). O. lobularis uses two modes of asexual reproduction: fragmentation and budding (Figure 5.2a and b).

Like sexual reproduction (see next section), fragmentation occurs once a year and often concerns most individuals of the same population. This event may be correlated with the switch to a short-day photoperiod and/or the decrease of water temperature (Fierro-Constain 2016; Rocher et al. 2020). At fall (October-November), adult individuals tend to elongate their tissues, and fragments seem to "dribble" until they separate totally (Figure 5.2b). The fate of the set-free fragments has not been monitored by any study yet, but it is supposed that these fragments can fall on a deeper substrate or be transported by the water flow; then some of them may be able to settle on rocks and develop into whole individuals.

In contrast, budding seems to occur at different periods during the year, between October and April (Figure 5.2b). This event appears not to be synchronized between individuals of the same natural population. It is therefore difficult to extrapolate the parameters triggering budding in the sea. Interestingly, budding can be triggered in vitro in $O$. lobularis by a mechanical stress, allowing for the monitoring and description of the whole process under laboratory conditions (Rocher et al. 2020).

The genesis and development of buds differ among sponge species (Ereskovsky et al. 2017a; Singh and Thakur 2015). In $O$. lobularis, the budding is performed in three key steps observed in a comparable manner during lab-induced budding in vitro and during natural budding of individuals in situ (Ereskovsky and Tokina 2007; Rocher et al. 2020). The budding process involves the evagination of adult tissues. The first step of budding is characterized by a transition from a smooth surface to an irregular surface. In the second step, small protrusions, responsible for this irregular aspect, grow apically to form branched finger-like structures at the surface of the adults. The third step consists of the swelling of protruding tissues and the release of free spherical buds. Once free, buds are able to float in the water flow and, in vitro, they have a much longer longevity than larvae: up to three months for Oscarella buds (Rocher et al. 2020 and for the buds of other species Maldonado and Riesgo 2008) versus a few days for larvae (Ereskovsky et al. 2009b; Ereskovsky et al. 2013a; Maldonado and Riesgo 2008). In standardized lab conditions, spherical buds develop outgrowths involved in the fixation to the substrate in a couple of days and an exhalant tube (osculum) in about one week, and settled juveniles can be obtained after one month (Rocher et al. 2020). These juveniles have a similar anatomy to that of juveniles resulting from sexual reproduction (Ereskovsky and Tokina 2007; Ereskovsky et al. 2007; Rocher et al. 2020) (Figure 5.2a).

We speculate that all together, the high number of buds produced by the same adult (mean 450 buds $/ \mathrm{cm}^{3}$ of adult tissue) with the floating properties of buds and their longevity (Rocher et al. 2020) make budding a crucial reproductive event in the O. lobularis life cycle (Fierro-Constain 2016). Asexual reproduction by budding must play an important role in the dispersion and population dynamics in natural habitats in $O$. lobularis, as proposed in demosponges (Cardone et al. 2010; Singh and Thakur 2015).

\subsubsection{Sexual Reproduction, Gametogenesis aNd INDIRECt DeVElopment}

Sexual reproduction takes place once a year (Figure 5.2b). A first analysis of 303 individuals of $O$. lobularis sampled monthly between 2006 and 2009 (Ereskovsky et al. 2013a) 
revealed that spermatogenesis occurred between June and August, differentiation of oocytes started in May and occurred until mid-August and embryogenesis occurred from mid-July to the beginning of September. A more recent study (2014-2015) based on both histological section observations and the detection of germline gene expression by in situ hybridization enabling a more efficient detection of earlier stages of gametogenesis allowed extension of the gametogenesis period from May-August to April-October (Fierro-Constain 2016; Fierro-Constaín et al. 2017; Rocher et al. 2020). Nevertheless, the latter study was performed on only six individuals of a population, this population being different from that considered in the previous study. This therefore does not preclude the differences observed between these studies being caused either by variations between populations or by different climatic conditions between the years considered.

Spermatogenesis and oogenesis co-occur from May to the beginning of September (Figure 5.2b), which provides an opportunity to decipher whether $O$. lobularis is a gonochoristic or hermaphroditic species. The in situ monitoring of localized and identified individuals in a small population suggests that $O$. lobularis is a hermaphrodite proterogyn (Fierro-Constain 2016; Fierro-Constaín et al. 2017). Both spermatocysts and oocytes were observed in the same individual as already shown in the early 20th century (Meewis 1938), and oogenesis starts earlier (April) than spermatogenesis (May). In contrast, the study of Ereskovsky et al. (2013a) suggested that this species is gonochoristic. This discrepancy may be explained by the fact that the number of oocytes and spermatocysts varies from one individual to another
(Fierro-Constain 2016) and between years (Ereskovsky et al. 2013a). Nevertheless, to solve this uncertainty, we suggest that applying Fierro-Constain's approach to a higher number of individuals of different populations would be useful.

Oscarella lobularis, like all other sponges, lacks gonads as well as germ cell lineage (reviewed in Ereskovsky 2010; Leys and Ereskovsky 2006; Simpson 1984). In this context, gametes form by transdifferentiation from somatic cells with stemness properties. In $O$. lobularis, both oocytes and spermatocysts are formed by the transdifferentiation of somatic cells involved in filtration, the choanocytes (Ereskovsky 2010; Gaino et al. 1986a; Gaino et al. 1986c). It has been shown that 11 genes of the germline multipotency program (GMP) are expressed during both the spermatogenesis and oogenesis of $O$. lobularis, suggesting that the RNAs and proteins encoded by these genes are involved in gametogenesis, as described in bilaterians (Fierro-Constaín et al. 2017).

Concerning spermatogenesis, all choanocytes of the same choanocyte chamber transdifferentiate into sperm cells, and the previous choanocyte chamber becomes a spermatocyst (Figure 5.2b). Not all choanocyte chambers are concerned in the same individual, enabling the reproductive adult to continue filter feeding. Spermatocysts (size ranging from 50 to $150 \mu \mathrm{m})$ are randomly distributed in mesohyl and produce several asynchronous generations of male germ cells. Spermatogonia derive directly from choanocytes and will develop to produce spermatozoa by a process of centripetal differentiation, as in many other animals. During this process, spermatogonia lose morphological characteristics and histological attributes of the choanocytes (Ereskovsky 2010; Ereskovsky et al. 2013a). Spermatozoa harbor a long flagella

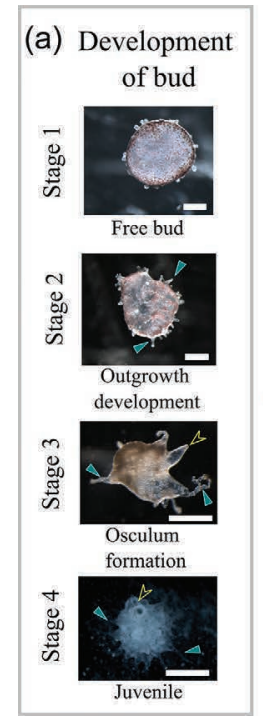

(b) Reproduction

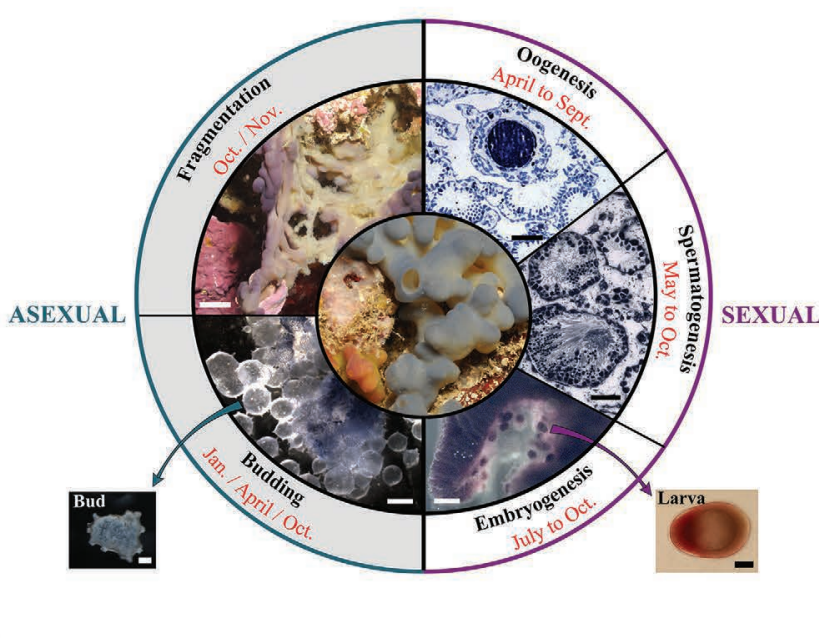

(c) Embryogenesis
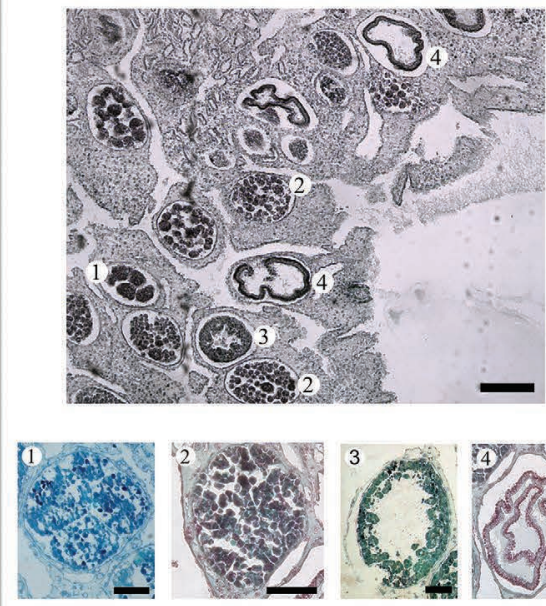
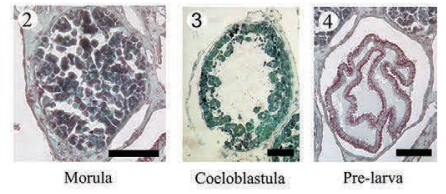

FIGURE 5.2 (A) Developmental stages from the release of free-buds to a settled juvenile (Rocher et al. 2020). Scale bars represent $500 \mu \mathrm{m}$ (stage 1 to 4). Blue and yellow arrows indicate, respectively, outgrowths and osculum. (b) The three modes of reproduction of Oscarella lobularis during a year: asexual reproduction by fragmentation (scale bar: $1 \mathrm{~cm}$ ) or budding (scale bar: $1 \mathrm{~mm}$ ) and sexual reproduction: oogenesis (scale bar: $50 \mu \mathrm{m}$ ); spermatogenesis (scale bar: $25 \mu \mathrm{m}$ ); embryogenesis (scale bar: $1 \mathrm{~mm}$ ). Swimming larva scale bar: $150 \mu \mathrm{m}$. Free bud scale bar: $200 \mu \mathrm{m}$. (c) Developmental stages occurring in the adult tissues from the zygote (resulting from internal fertilization) to the cinctoblastula pre-larva. Scale bar represents $200 \mu \mathrm{m}$. (1): Four-cell stage; (2): morula stage; (3): coeloblastula stage; (4): cinctoblastula pre-larva. Scale bars represent $50 \mu \mathrm{m}$ (Stages 1 to 4). 
and a slightly elongated head with an acrosome and a large mitochondrion (Ereskovsky 2010; Ereskovsky et al. 2013a; Gaino et al. 1986a). Spermatozoa are released into the surrounding water by the oscula via the exhalant canals.

Concerning oogenesis, a few choanocytes migrate into the mesohyl and transdifferentiate into oocytes (Figure $5.2 \mathrm{~b})$. The size of the young spherical oocyte corresponds to the size of one choanocyte $(7-10 \mu \mathrm{m})$ without flagellum, microvilli and basal filopodia. This size increases significantly during vitellogenesis, although the final size of a mature oocyte is different, according to the authors (Ereskovsky 2010; Ereskovsky et al. 2013a; Fierro-Constain 2016). In this species, the great amount of vitellus (polylecithal eggs), uniformly distributed in the ooplasm (isolecithal), is produced by endogenous synthesis (Ereskovsky 2010; Ereskovsky et al. 2009b; Gaino et al. 1986b), unlike the other sponges with polylecithal oocytes in which vitellogenesis occurs by phagocytosis of somatic cells and/or bacteria (Maldonado and Riesgo 2008). Mature oocytes, located in the basal zone of the choanosome, are enclosed by endopinacoderm to form a so-called follicle. Before the closure of the follicle, maternal symbiotic bacteria and several maternal cells penetrate in the space between the oocyte and the follicle (Ereskovsky and Boury-Esnault 2002). Vertical transmission of symbionts from embryo to juvenile has been well documented in sponges (Boury-Esnault et al. 2003; Ereskovsky 2010; Ereskovsky and Boury-Esnault 2002; Ereskovsky et al. 2007; Ereskovsky et al. 2009b). Moreover, the penetration of maternal vacuolar cells inside of follicles was described in many investigated sponge species from the classes Demospongiae, Calcarea and Homoscleromorpha (Ereskovsky 2010). The oocytes remain in the adult tissue, meaning that $O$. lobularis performs internal fertilization. As fertilization per se has never been observed in this species, it is unknown whether it relies upon a carrier-cell system, as described in Calcaronea species (first described by Gatenby in 1920; reviewed in Ereskovsky 2010).

\subsection{EMBRYOGENESIS}

\subsubsection{Cleavage and Formation of Coeloblastula}

Like many sponge species described so far, Oscarella lobularis undergoes indirect development (Ereskovsky 2010). Additionally, as a direct consequence of internal fertilization, O. lobularis is a "brooding" sponge. This means that the development from a zygote to a fully developed larva (cinctoblastula) occurs within the adult tissue (Figure 5.2c): swimming larvae are then released in the surrounding water (Figure 5.2b).

The embryonic development of $O$. lobularis is similar to other species of the genus Oscarella. The main steps of this embryonic development have been described so far only by classical histological approaches on fixed individuals (Ereskovsky 2010; Ereskovsky and Boury-Esnault 2002; Ereskovsky et al. 2009b; Ereskovsky et al. 2013a;
Ereskovsky et al. 2013b; Leys and Ereskovsky 2006). As in all Metazoa, the first developmental step consists of the cleavage of the zygote. The zygote being isolecithal (see previous section on oogenesis), this cleavage is holoblastic. The first two divisions (until the four-cell stage; Figure 5.2c) are equal and synchronous. Then the cleavage becomes irregular and asynchronous from the third division. After six divisions, the morula stage is reached: the morula is composed of 64 undifferentiated blastomeres (Ereskovsky and Boury-Esnault 2002; Ereskovsky et al. 2013a; Leys and Ereskovsky 2006) (Figure 5.2c). As cleavage progresses, the blastomeres reduce in size, and the volume of the embryo remains unchanged.

From the 64-cell morula stage, the blastomeres at the surface of the morula divide more actively, while internal blastomeres migrate to the periphery of the embryo through a process of multipolar egression (Ereskovsky 2010; Ereskovsky and Boury-Esnault 2002; Ereskovsky et al. 2013a; Leys and Ereskovsky 2006) to form a monolayered coeloblastula with a central cavity (Figure 5.2c). This central cavity has been described as containing the maternal symbiotic bacteria and maternal vacuolar cells (see previous section on oogenesis). The role and fate of these latter have not been explored and will have to be with modern molecular and cellular tools (Boury-Esnault et al. 2003; Ereskovsky and Boury-Esnault 2002; Ereskovsky et al. 2007; Ereskovsky et al. 2013a), but they seem to degenerate during metamorphosis of the larvae (personal observations).

Unlike in the three other sponge classes, the coeloblastula of Oscarella exhibits a monolayer columnar epithelium. This epithelium fits all classical criteria of the definition of epithelia in Bilaterians (Ereskovsky et al. 2009b; Leys and Riesgo 2012; Leys et al. 2009; Tyler 2003; Renard et al. 2021). i) Cells are highly polarized: cilia develop at the apical cell pole; ii) cells are tightened by specialized intercellular junctions, similar to adherens junctions, in the apical domain; and iii) cells are lined at their basal pole by a basement membrane consisting of collagen IV (Boute et al. 1996; Ereskovsky and Boury-Esnault 2002; Boury-Esnault et al. 2003). The establishment of this columnar epithelium at the coeloblastula stage is the first sign of cellular differentiation processes. Note that, even if the term "coeloblastula" was used in the literature because of the presence of a central cavity, this organization is not the result of the same processes (cleavage only) as in other metazoans (BouryEsnault et al. 2003; Brusca and Brusca 2003; Ereskovsky 2010; Ereskovsky and Boury-Esnault 2002; Ereskovsky and Dondua 2006; Leys 2004; Leys and Ereskovsky 2006; Maldonado and Riesgo 2008; Wörheide et al. 2012). For this reason, some authors prefer the use of the term "prelarva" or "cinctoblastula prelarva" (Ereskovsky 2010). Unfortunately, this complex terminology makes comparison with other metazoans very difficult, and none of the embryological descriptions of embryological development available so far in sponges are based on live observations and cell tracking experiments. 


\subsubsection{Morphogenesis of the Cinctoblastula Larva and Larval Metamorphosis}

Cells continue to divide, thus increasing the cell surface area. Because of the limited space in the follicle, the external epithelium becomes folded (Figure 5.2c). The central cavity is progressively filled by collagen fibrils, and a pronounced antero-posterior polarity is acquired: the ciliated cells contain various cytoplasmic inclusions and present a variable nucleus position according to their position along the anterior-posterior axis, unlike in coeloblastula larva of other sponges (Boury-Esnault et al. 2003; Ereskovsky 2010; Leys and Ereskovsky 2006). The cellular mechanisms by which pre-cinctoblastula larvae are transferred from the mesohyl to the exhalant canal was described in Boury-Esnault et al. (2003) and involves a fusion between the endopinacoderm forming the follicles and the endopinacoderm lining the canals. Finally, a free-swimming cinctoblastula larva is released from the adult sponge through the exhalant canals and the osculum. Larvae are uniformly flagellated (despite the presence of few scattered non-ciliated cells) and present a polarity: the anterior pole is larger than the posterior one, and the posterior pole is pigmented (pink pigments in $O$. lobularis) and rich in symbiotic bacteria and maternal vacuolar cells in the central cavity. The pigments are probably involved in the observed larval phototaxis behavior, as evidenced in the demosponge Amphimedon queenslandica (Degnan et al. 2015; Leys and Degnan 2001; Rivera et al. 2012).

The larva can swim in the water column for several days before settlement. The larva attaches to the substrate by the anterior pole thanks to mucus secretion, then undergoes metamorphosis (Figure 5.3a). Therefore, the A/P axis of the larva corresponds to the baso-apical axis of the juvenile sponge.

During metamorphosis, the larva undergoes radical morphological and physiological changes. The metamorphosis of the larva represents a second phase of reorganization of cell layers and corresponds to the acquisition of the typical sponge bauplan with a functional aquiferous system. The formation of the two main epithelial layers, namely the pinacoderm and the choanoderm, occurs through the transdifferentiation of the larval epithelium (fully detailed in Ereskovsky 2010; Ereskovsky et al. 2007; Ereskovsky et al. 2010).

The steps of larval metamorphosis have been described as variable and independent of environmental factors (Ereskovsky et al. 2007). However, the origin of this polyphenism is unknown. In most cases, the metamorphosis of O. lobularis larvae begins by a basal invagination (Figure 5.3a). In parallel to this invagination, several lateral cells ingress into the cavity. The lateral then sides fold up with the subsequent involution of marginal sides. At this stage, the future juvenile is composed of two cell layers, an external layer, from which the future exopinacoderm will originate, and an internal layer. The cells of this internal layer become flat, thereby increasing the tissue surface, which itself results in folding. This inner folded epithelium gives rise to the aquiferous system: the endopinacoderm is derived from the proximal parts of the internal cell layer, while the choanocyte chambers develop from distal parts of the internal folds (Figure 5.3a). The inhalant pores, ostia, and the exhalant pores, osculum, are formed secondarily. A settled filtering juvenile is finally formed, usually called a "rhagon".

\subsubsection{Molecular Control of Development}

The molecular mechanisms controlling the previously described developmental events are still unknown. As sexual reproduction occurs only once a year and embryos are not observed every year in sampled adults, and furthermore the embryos are intimately embedded in the adult tissues, their dissection and manipulation are rather tricky. Therefore, only two studies so far report gene expression patterns during embryogenesis. Due to the key role of the WNT pathway in axial patterning across the animal kingdom, several studies have investigated the pattern of Wnt gene expression during sponge development or during other morphogenetic processes (Adamska 2016; Adamska et al. 2007; Adamska et al. 2010; Adamska et al. 2011; Borisenko et al. 2016; Degnan et al. 2015; Lanna 2015; Leininger et al. 2014; Richards and Degnan 2009). In Oscarella lobularis, nine Wnt genes were found, as well as their target genes (Lapébie et al. 2009; Schenkelaars 2015). Even though most Wnts and $F z d s$ genes are uniformly expressed during early stages of embryogenesis without apparent gradient or asymmetry, one Wnt gene is clearly localized at one pole of the embryos before any morphological polarity is observed (Schenkelaars 2015). This latter observation is in agreement with results obtained in other sponge lineages (Calcarea and Demospongiae), where WNT ligands and downstream genes are expressed in the posterior region of the embryos or larvae (Adamska 2016; Adamska et al. 2007; Adamska et al. 2010; Borisenko et al. 2016; Degnan et al. 2015; Leininger et al. 2014). These expression patterns tend to support a putative involvement of WNT pathways in patterning of the major sponge body axis. In addition, Fierro-Constaín et al. (2017) showed that 11 genes of the GMP are expressed during embryogenesis (including the most famous piwi, vasa, nanos, Pllo genes). This finding agrees with observations in other animals. Interestingly, among these genes, nanos harbors a highly polarized pattern in the prelarva: with a much higher expression level at the anterior pole. Such a polarized pattern was also observed in the calcarean sponge Sycon ciliatum (Leininger et al. 2014) and in other metazoans, but the role of this gene in axis patterning is unclear (Kanska and Frank 2013).

\subsection{ANATOMY}

As previously explained, developmental processes following both sexual and asexual (by budding) reproduction result 
(a) Larval metamorphosis
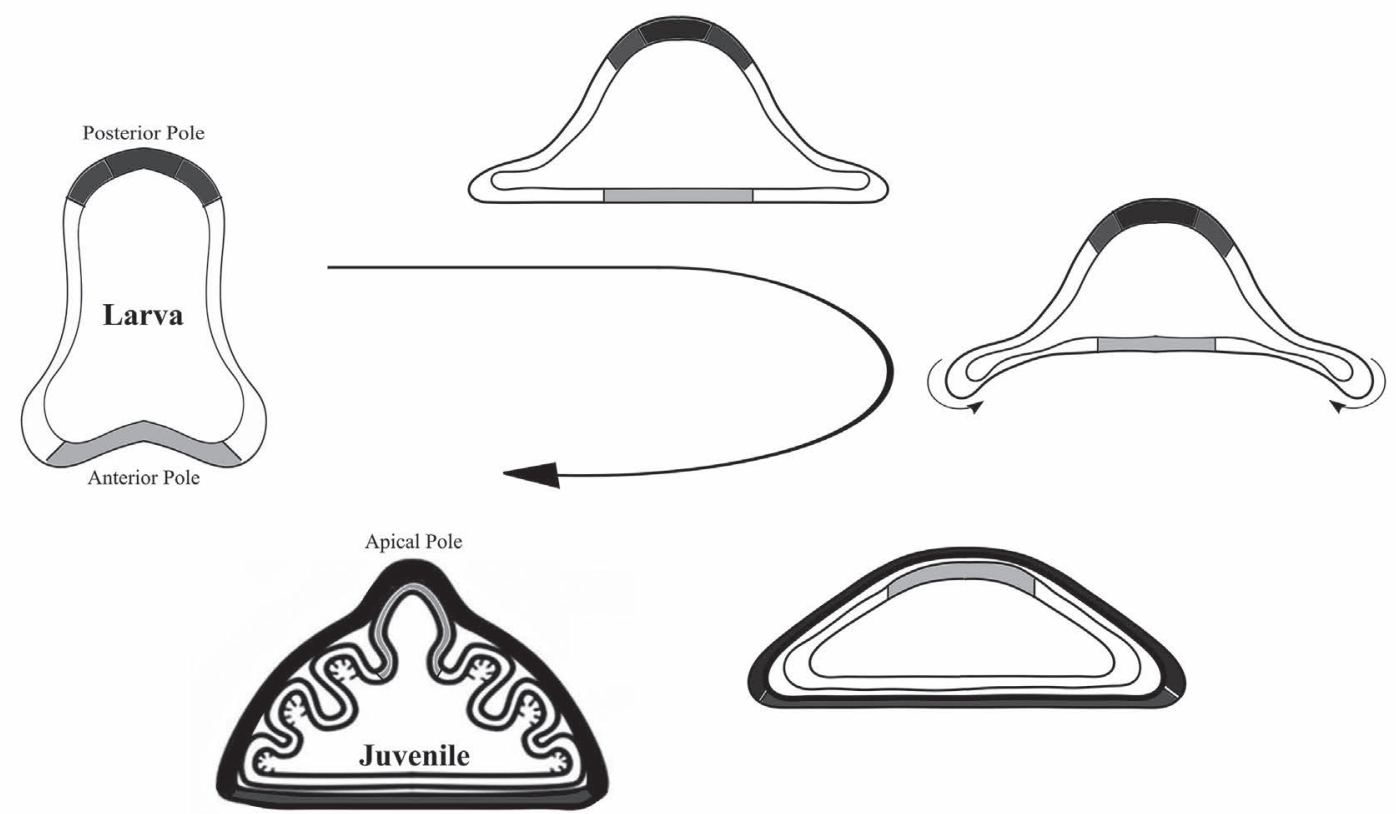

Basal Pole

(b) Anatomy

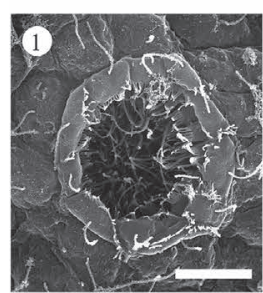

Apolylar cell

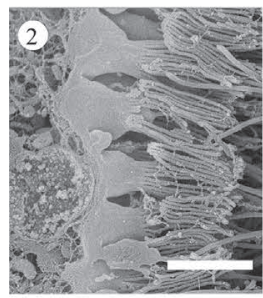

Choanocytes

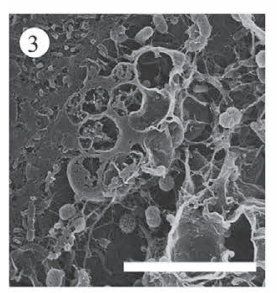

Type II vacuolar cell

Archeocyte

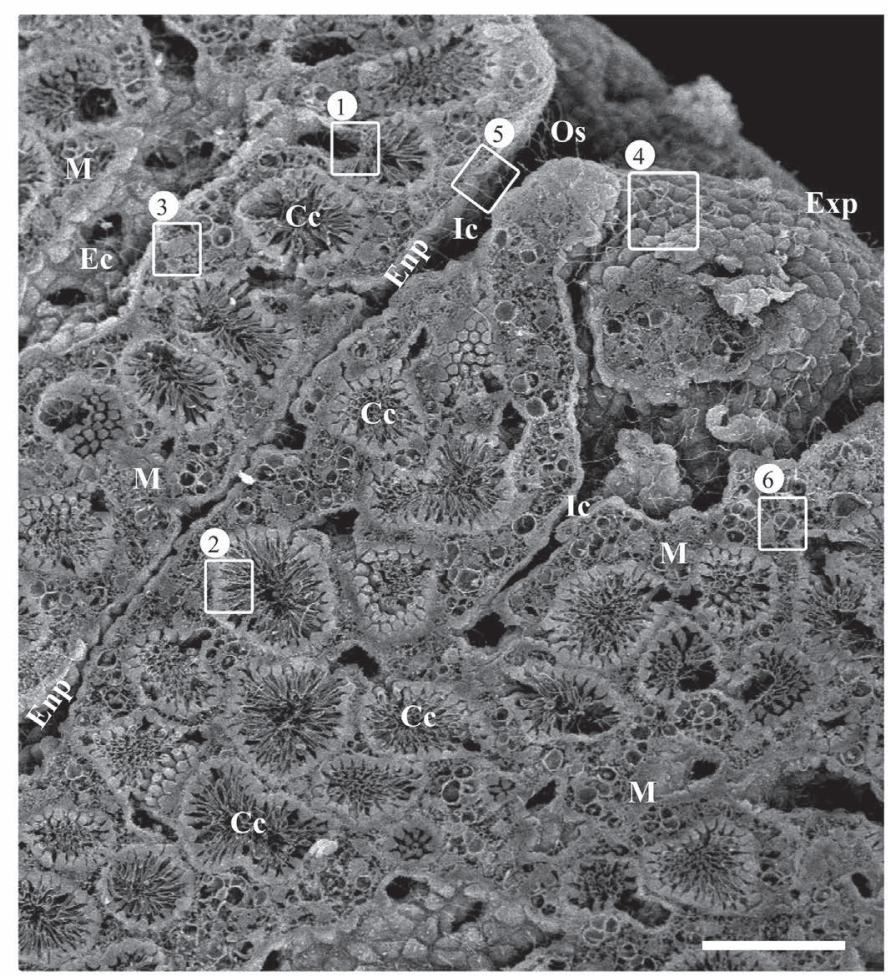


in the formation of sessile juveniles of Oscarella lobularis with a clear baso-apical polarity and a simple but functional aquiferous system. Juveniles differ in size (small, about 2 $\mathrm{mm}$ in length and height), color (whitish) and shape (more or less conic instead of asymmetric and multilobated) compared to adults but harbor the same main features as observed at the adult stage (Figure 5.3b).

As is the case for all other sponges, whatever their class, the adult stage of $O$. lobularis is devoid of organs, with no neuron, no muscle and no digestive cavity. $O$. lobularis adults, like most other sponges (except in the case of carnivorous demosponges; Vacelet and Boury-Esnault 1995) are sessile filter-feeders organized around a circulatory aquiferous system with a sylleibid organization (Figure 5.3b). Water flow enters through the incurrent or inhalant pores, named ostia, and is transported via the inhalant canals to the choanocyte chambers. In the choanocyte chambers, the beating of choanocyte flagella is responsible for the internal water flow, and the apical microvilli collar of choanocytes capture unicellular organisms. Trapped food particles are then phagocytized by choanocytes. The filtered water leaves choanocyte chambers via exhalant or excurrent canals and finally exits from the sponge by a large exhalant tube named the osculum.

The tissues of Oscarella lobularis consist of two epithelial cell layers: the pinacoderm and the choanoderm. These two layers rest on a basement membrane composed of type IV collagen (and probably of tenascin and laminin as well, as suggested in the sister species $O$. tuberculata; Humbert-David and Garrone 1993), and the epithelial cells are connected by junctions histologically similar to adherens junctions, like in the larvae (Boury-Esnault et al. 2003; Boute et al. 1996; Ereskovsky 2010; Ereskovsky et al. 2007; Ereskovsky et al. 2009b; Leys and Riesgo 2012; Leys et al. 2009) and like in buds (Rocher et al. 2020). Between these two epithelial layers, there is a loose mesenchymal layer, the mesohyl.

\subsubsection{The Pinacoderm}

In Oscarella lobularis, the pinacoderm is composed of pinacocytes organized in a monolayered squamous ciliated epithelium (Figure 5.3b). This epithelium is covered by glycocalyx and mucus layers secreted by pinacocytes. Depending on their localization, different types of pinacocytes are distinguished: the endopinacocytes line all inhalant and exhalant canals, the exopinacocytes compose the outermost layer of the body and the basopinacocytes are involved in the attachment to the substratum. According to the previously described embryology of this species, basopinacoderm and exopinacoderm originate from the same external layer of the rhagon, whereas endopinacoderm originate from the inner one.

In adults, no study has examined whether the pinacocyte cilia are motile or non-motile; in contrast, the beating of exopinacocyte cilia has been evidenced at the bud stage (Rocher et al. 2020). The authors demonstrate that a directional flow of particles (microfluorescent beads in that case) on the surface of the body is directly correlated with the exopinacocyte cilia beating. Indeed, a nocodazole treatment, well known to be a microtubule inhibitor, stops both cilia beating and the bead flow. We can extrapolate that a similar process acts at the adult stage and that the directional flow of particles (probably trapped by the external mucus) may help their convergence to the ostia and hence their absorption in the aquiferous system. Such a mechanism is akin to the ciliary-mucoid feeding process described in other suspension feeder animals (Riisgård and Larsen 2017). This hypothesis still remains to be tested by live physiological experiments.

\subsubsection{The Choanoderm}

In Oscarella lobularis, as in other sponges with leuconoid or sylleibid aquiferous systems, the choanoderm is organized in a multitude of hollow spheres named choanocyte chambers (Figure 5.3b). The choanoderm is formed by a cell type, the choanocyte, the key player of water filtration thanks to its typical microvilli collar and flagellum (whose orthology with choanoflagellate cells has been debated; Adamska 2016; Brunet and King 2017; Colgren and Nichols 2019; Dunn et al. 2015; King 2004; Laundon et al. 2019; Mah et al. 2014; Maldonado 2004; Nielsen 2008; Pozdnyakov et al. 2017; Sogabe et al. 2019). Like the pinacoderm, the choanoderm is a monolayered epithelium. In contrast to pinacocytes, choanocytes are conic cells. The filtering activity has been shown to be an active process in the bud, based on flagella beating, the arrest of beating (by nocodazole) resulting in the absence of particle absorption (Rocher et al. 2020). This observation is easily transposable to the adult stage because of previous studies in other sponges (Leys and Hill 2012; Leys et al. 2011; Ludeman et al. 2017). As in demosponges, choanocytes, even though they are a highly specialized cell type, have stemness properties: dividing activity, expression of GMP genes and capability of transdifferentiation into other cell types (Alié et al. 2015; Borisenko et al. 2015; Fierro-Constaín et al. 2017; Funayama 2013; Funayama 2018; Funayama et al. 2010; Sogabe et al. 2016).

The choanocyte chambers have large openings (eurypylous choanocyte chambers), and the opening toward exhalant canals is surrounded by a particular type of cell, named apopylar cells, which harbors an intermediate morphology between endopinacocytes and choanocytes. This cell type has been supposed to play an important role in controlling water flow in the aquiferous system (Hammel and Nickel 2014; Leys and Hill 2012).

\subsubsection{The Mesohyl}

The mesohyl is a mesenchymal layer. It is the inner part of the sponge body, never in direct contact with the water flow. Extracellular matrix is the main component of this layer. Extracellular bacteria are found in this internal compartment. Studies carried out by transmission electronic 
microscopy (TEM), by denaturating gradient gel electrophoresis (DGGE) or by $16 \mathrm{~S}$ sequencing have shown that $O$. lobularis is a low microbial abundance (LMA) sponge (Gloeckner et al. 2013; Vishnyakov and Ereskovsky 2009). Its phylum-level microbial diversity is represented by three bacterial phyla with a large dominance (76\%) of Proteobacteria. Phylogenetic analysis revealed four sequences affiliated with Verrucomicrobia, three with Gammaproteobacteria and two sequences with Bacteroidetes, and the 16 remaining sequences were affiliated with Alphaproteobacteria. Moreover, microbial diversity is neither significantly different between color morphs nor between individuals of different locations or depths (Gerçe et al. 2011; Gloeckner et al. 2013). More recently, metagenomic analyses suggest that the main bacterial symbiot of $O$. lobularis is an Alphaproteobacteria of the Rhodobacteriaceae family. This new species was named Candidatus Rhodobacter lobularis, it is about 20-fold more numerous than sponge cells in the mesohyl and its draft genome is available (Jourda et al. 2015). Even though no physiological studies have yet been performed to identify the mutual benefits of this association, members of the Rhodobacter group often perform aerobic anoxygenic photoheterotrophy (Labrenz et al. 2009; Pohlner et al. 2019; Sorokin et al. 2005); we therefore suggest that hosting such Rhodobacter species may supply $O$. lobularis with carbon.

In addition, several sponge cell types are present in the mesohyl (Figure 5.3b). Classically, photonic and electronic observations have defined two cell types: type I vacuolar and type II vacuolar (Boury-Esnault et al. 1992; Ereskovsky et al. 2009b). Type I vacuolar cells are characterized by two to four large empty vacuoles and a small nucleus placed laterally, and their role is unknown. Type II vacuolar cells are amoeboid cells with numerous filopodia, numerous small vacuoles and a large nucleus with a nucleolus. Because of these cytological features and the fact that these cells express 11 genes of the GMP program, they were supposed to correspond to what are defined as archaeocytes in other sponges (Fierro-Constaín et al. 2017). Comparative singlecell transcriptomic data are now awaited to establish homology between cell types between sponge species and to make clearer the sponge cell type terminology only based on cell morphology (De Vos et al. 1991; Musser et al. 2019; Rocher et al. 2020; Sogabe et al. 2019). Interestingly, the use of scanning electron microscopy and immunofluorescent techniques resulted in the identification of at least one additional cell type in the mesohyl of $O$. lobularis bud: a third vacuolar cell type (Rocher et al. 2020). Additionally, numerous, previously undescribed, tiny anucleate cell-like structures were interpreted as apoptotic extracellular vesicles (EVs) (Rocher et al. 2020). Because buds originate directly from adult tissues (see previous sections), we do not believe that these type III vacuolar cells and EVs are bud specific but rather that they were not observed on adults until now because of technical limitations. These recent findings highlight the subjectivity of cell type definition, and again, much is expected from ongoing single cell transcriptomic approaches to define cell types on the basis of a shared regulatory network (Arendt et al. 2016).

\subsection{TRANSCRIPTOMIC AND GENOMIC DATA}

Since the first genome of the demosponge Amphimedon queenslandica was published (Srivastava et al. 2010), sponge genomic resources have significantly increased (for review, see Renard et al. 2018 and references included, plus Kenny et al. 2020). These data revealed that sponges have a genome size and number of genes comparable to those of most invertebrates. In addition, these studies indicate striking genome feature differences between sponge species even within the same class: differences in predicted genome size (from 57 to $357 \mathrm{Mb}$ ) in agreement with very variable DNA content evidenced by old cytogenetic approaches; differences in ploidy (diploidy or probable tetraploidy in Calcarea), amount and length of non-coding regions and genes present, among others (Kenny et al. 2020; Renard et al. 2018; Santini et al. in prep).

Concerning Oscarella lobularis, a genome draft was sequenced with illumina technology (Belahbib et al. 2018); ongoing additional sequencing efforts are expected to improve the assembly of this genome in a near future. At present, the predicted length of the genome of $O$. lobularis is $52.34 \mathrm{Mb}$ (Belahbib et al. 2018); this is even smaller than what was predicted for $O$. pearsei $(57.7 \mathrm{Mb}$; Nichols et al. 2006). If confirmed when a better assembly is obtained, this genome would represent the smallest sponge genome reported so far. This genome is predicted to contain 17,885 protein-coding genes (Belahbib et al. 2018). This is surprisingly low compared to demosponges: Ephydatia muelleri is supposed to harbor 39,245 protein-coding genes (Kenny et al. 2020), Amphimedon queenslandica 40,122 (FernandezValverde et al. 2015) and Tethya wilhelma 37,416 (Francis et al. 2017). We are expecting a better genome assembly for both $O$. pearsei and $O$. lobularis in order to be able to decipher whether these small genome sizes and low numbers of genes are due to sequencing pitfalls or represent a common feature of Oscarellidae genomes.

To date, only one study has used this genomic data to compare epithelial genes of $O$. lobularis to other sponges (Belahbib et al. 2018). All other comparative molecular studies published so far were either based on PCR approaches (Gazave et al. 2008; Lapébie et al. 2009) or on transcriptomic data obtained by 454 sequencing technology performed on a mixture of developmental stages (adult, embryos and larvae) to maximize the representativity of this transcriptome (Fierro-Constaín et al. 2017; Schenkelaars et al. 2015; Schenkelaars et al. 2016a).

These transcriptomic and genomic studies published thus far have focused on genes involved in epithelial functions, in Notch and WNT signaling and genes pertaining to the GMP. As far as the GMP and the canonical WNT pathways are concerned, genes present in $O$. lobularis are not different from what is found in other sponge classes (Fierro-Constaín et al. 2017; Lapebie 2010; Lapébie et al. 2009; Schenkelaars 2015; Schenkelaars et al. 2015). When comparisons are 
made at the level of gene content only, $O$. lobularis, like all other sponges, possesses all nine genes coding for proteins involved in the establishment of the CRUMBS, PAR and SCRIBBLE complexes of bilaterians needed to establish cell polarity, as well as all three genes encoding proteins needed to establish the cadherin-catenin complex (CCC) required for the formation of adherens junctions (namely alpha, beta and delta catenins as well as classical cadherin) (Belahbib et al. 2018). However, key functional domains and motif sequences are amazingly more conserved in $O$. lobularis than they are in other sponge classes. For example, PatJ protein (one of the three components of the crumbs polarity complex containing Crumbs, MPP5 and PatJ) binds MPP5 via the L27 domain: The L27 domain sequence is more conserved in $O$. lobularis compared to the other sponges (Belahbib et al. 2018). It is the same for cadherin $/ \beta$-catenin $/ \alpha$-catenin complex. The comparison of the E-cadherin cytoplasmic tail, which contains the conserved specific binding domain for delta-catenin and $\beta$-catenin, is more conserved in O. lobularis than in other sponges relative to bilaterian sequences (Belahbib et al. 2018).

Concerning pathways commonly involved in epithelial patterning, it was shown that $O$. lobularis possesses all the core gene encoding for proteins needed to establish a planar cell polarity (PCP) pathway. Indeed, Strabismus (Stbm)/Van Gogh (Vang), Flamingo (Fmi), Prickle (Pk), Dishevelled (Dsh) and frizzled (Fzd) proteins are present in O. lobularis (Schenkelaars 2015; Schenkelaars et al. 2016a), whereas other sponges lack either one or several members of this pathway (Fmi, Fzd and/or Vang) (Schenkelaars 2015; Schenkelaars et al. 2016a) (Figure 5.4a). This finding challenged previous studies in Ctenophora and Porifera suggesting that the PCP pathway arose in the last common ancestor of Parahoxozoa (Bilateria, Cnidaria and Placozoa) (Adamska et al. 2010; Ryan et al. 2013), meaning that the PCP pathway may date back to the emergence of Metazoa. This unexpected result calls for functional studies in O. lobularis: Is this pathway involved in the coordination and orientation of exopinacocyte cilia (Figure 5.4b and c) in the same way it is in other animals (Devenport 2014; Schenkelaars et al. 2016a; Wallingford 2010)?

Other key genes considered absent in other sponge classes are present in O. lobularis. This is notably the case for the Hes gene belonging to group E bHLH transcription factors. To date, only Hey genes have been reported in Demospongiae and Calcarea (Fortunato et al. 2016; Simionato et al. 2007; Srivastava et al. 2010); in contrast, $O$. pearsei and O. lobularis possess bona fide Hes (Gazave 2010; Gazave et al. 2014) (Figure 5.4d). This means that this gene was ancestrally present in the last common ancestor of Porifera and was lost in other sponge classes. This finding offers additional possibilities to test the respective roles of canonical and non-canonical Notch signaling pathways in Metazoa and notably to explore the role of Notch signaling in animals devoid of neurons (Layden et al. 2013).

Despite a lack of neurons and conventional neurotransmitters, sponges perceive and respond to a large range of stimuli. In animals, Glutamate is the principal excitatory neurotransmitter in the central nervous system. All sponges have a number of metabotropic glutamate (mGlu) and GABA receptors, suggesting that glutamatergic signaling is common in sponges (Leys et al. 2019). In contrast, the ionotropic glutamate receptor iGluR gene is found only in calcareous sponges and homoscleromorphs (Figure 5.4e) (Ramos-Vicente et al. 2018; Renard et al. 2018; Stroebel and Paoletti 2020). However, the localization and function of these receptors remain to be identified in these animals devoid of neurons and synapses.

Much remains to explore in the transcriptome and genome of $O$. lobularis; nevertheless, according to the present knowledge, compared to other sponge classes, the homoscleromorph sponges $O$. pearse $i$ and $O$. lobularis seem to exhibit the most complete and conserved bilaterian gene repertoire (Babonis and Martindale 2017; Fortunato et al. 2015; Gazave et al. 2014; Renard et al. 2018; Riesgo et al. 2014; Schenkelaars et al. 2016a).

\subsection{FUNCTIONAL APPROACHES: TOOLS FOR MOLECULAR AND CELLULAR ANALYSES}

\subsubsection{Developmental and Non-Developmental Morphogenetic Contexts Accessible}

Embryos and larvae are accessible only once a year between August and October, and the reproductive effort is variable from one population to another and from one year to another (Ereskovsky et al. 2013a). Therefore, because sexual reproduction cannot be triggered in the laboratory, so far, the access to embryonic developmental processes remains very limited.

To compensate for this difficulty, experimental protocols were designed to access non-developmental morphogenetic processes (Table 5.2). Wound healing experiments have already been successfully used at the adult stage (Ereskovsky et al. 2015; Fierro-Constaín et al. 2017); wound-healing and regenerative experiments are now also mastered at the bud stage: stage 3 with osculum regenerates an osculum in less than four days (Rocher et al. 2020); cell-dissociation/ reaggregation experiments resulting in neo-epithelialized primmorphs (in less than three days) can be performed both on adults (unpublished data) and on buds (Rocher et al. 2020; Vernale et al. in press).

\subsubsection{Polymerase Chain Reaction and Relatives}

As in the case of other sponge species studied for evo-devo purposes, the first molecular studies undergone on Oscarella lobularis were performed using the polymerase chain reaction (PCR) technique. This resulted in the description of the phylogenetic relationships among Homoscleromorpha (described in the first section), including $O$. lobularis (Borchiellini et al. 2004; Gazave et al. 2010; Gazave et al. 2012; Gazave et al. 2013). The main pitfall faced during this simple classical PCR/cloning/sequencing was at the step of DNA extraction. For $O$. lobularis, as for other 


\section{"Classical" epithelial features and PCP pathway in Homoscleromorph sponges only?}
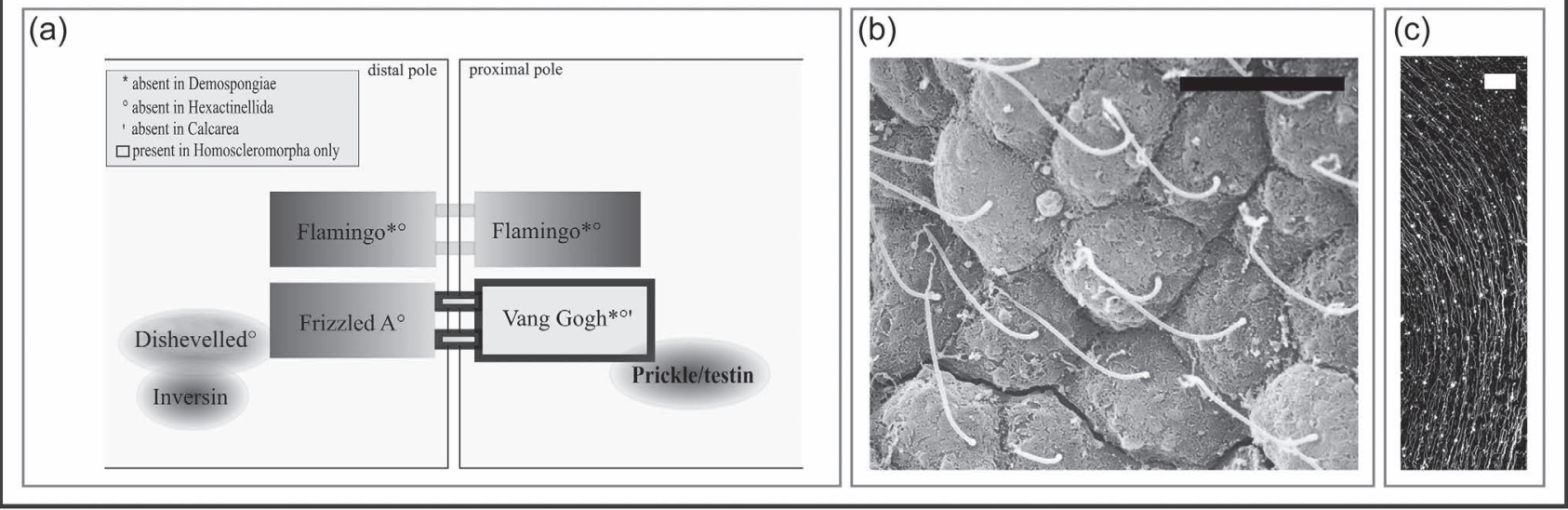

(d)

a key target of the canonical Notch signaling pathway in Homoscleromorph sponges only

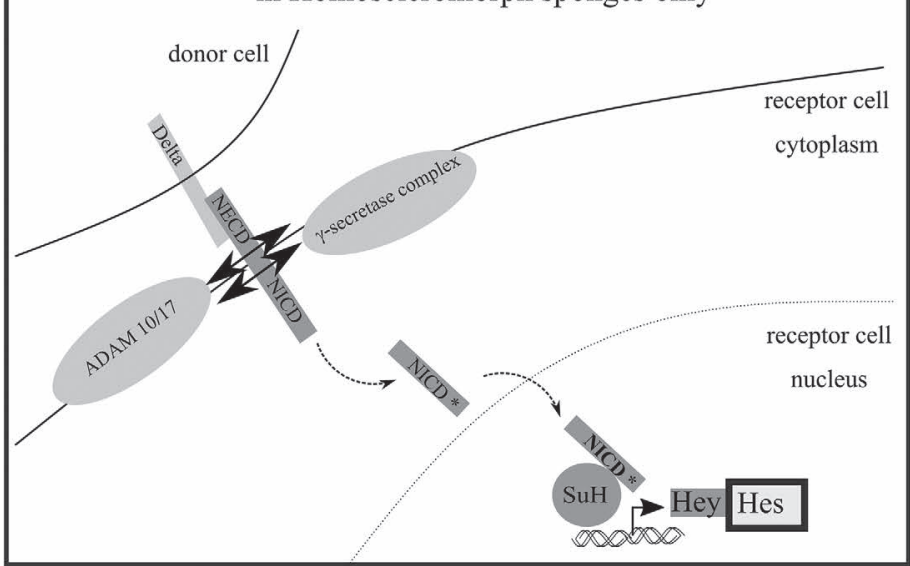

(e) ionotropic Glutamate Receptors (iGluR) in Calcarea and Homoscleromorpha only

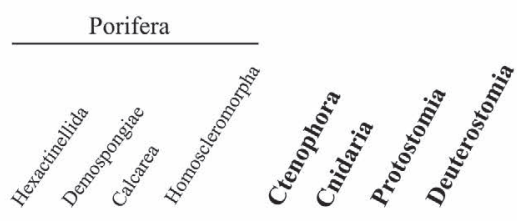

Glu L
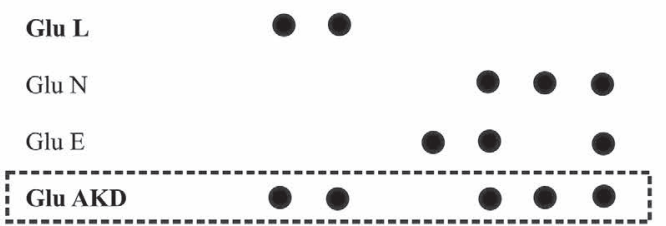

FIGURE 5.4 (a) The planar cell polarity pathway is involved in the establishment of a polarity between neighboring cells; the core members of this pathway are represented in this diagram: only Homoscleromorpha possess all these core members, whereas other sponge classes lack one to three of them. (b) Exopinacoderm of Oscarella lobularis showing cilia orientation. Scale bar: $10 \mu \mathrm{m}$. (c) The oriented beating of the cilia on the exopinacoderm was evidenced at the bud stage thanks to the monitoring of fluorescent beads. Scale bar: $50 \mu \mathrm{m}$. (d) Diagram of the core components of the canonical Notch signaling pathway conserved in sponges, Hes, was so far evidenced in the Oscarella genus only. (e) The ionotropic Glutamate receptors (iGluR) are split into four families (in Metazoa): the Glu L family is sponge specific, the Glu E family gathers all ctenophore $i G l u R s$ and genes present in cnidarians and deuterostomes and GluN genes are characterized in ctenophores and sponges but are found in all cnidarians and bilaterians, whereas the Glu AKD family is present from sponges to vertebrates (except ctenophores). Among sponge classes, Homoscleromorpha and Calcarea only have iGluR receptors. ([a] Schenkelaars et al. 2016a; [c] Rocher et al. 2020; [d] Fortunato et al. 2016; Gazave 2010; Gazave and Renard 2010; Gazave et al. 2009; Gazave et al. 2014; Simionato et al. 2007; [e] Stroebel and Paoletti 2020.)

Oscarella species, ethanol preservation of samples resulted in improving PCR results, probably by limiting the presence of pigments and secondary metabolites (Boury-Esnault et al. 2013; Ivanišević et al. 2011) in the tissues that might interfere with the PCR.

In parallel, a degenerated primer approach was used to search for sequences of homeobox genes encoding for transcription factors of the antennapedia (ANTP) class. This approach failed to retrieve the famous hox genes, as in other sponges, but $N K$-related genes were characterized (Gazave et al. 2008). Because of the usually high sequence divergence between sponge and bilaterian sequences, this PCR-based approach had low efficiency. The acquisition of expression sequence tag (EST) libraries (Lapébie et al. 2009; Philippe et al. 2009) and of a 454 transcriptome effectively made finding a candidate gene much easier (FierroConstain 2016; Gazave 2010; Lapebie 2010; Schenkelaars 2015). As far as PCR techniques are concerned, real-time PCR (or quantitative RTPCR [RT for reverse transcription]) was launched more recently, thereby providing the possibility of studying the expression of several genes in various conditions (Fierro-Constaín et al. 2017). For this sponge species, the mitochondrial gene Cytochrome Oxidase subunit 1 (CO I) and the nuclear genes Elongation Factor 1 (EF1) and glyceraldehyde-3-phosphate dehydrogenase $(G A P D H)$ are effective reference genes, because they have 
stable expression during their life cycle (Fierro-Constaín et al. 2017) but also under contaminant exposure conditions (de Pao Mendonca, unpublished data).

\subsubsection{In Situ Hybridization}

The in situ hybridization (ISH) technique is also mastered in Oscarella lobularis, thereby allowing access to qualitative data (localization) in addition to quantitative expression gene information provided by the previously mentioned real-time PCR. The first ISH data were acquired in 2008 (Gazave et al. 2008; Lapébie et al. 2009), and the protocol was subsequently improved (Fierro-Constaín et al. 2017; Fierro-Constaín et al. 2021). The ISH can be performed at all stages (adult, bud, larvae) on sections or in whole mounts. Fluorescent ISH (FISH) is also in progress (Prünster, unpublished data). For colorimetric ISH, 5-brom4-chloro-3'-indolyphosphate p-toluidine salt/nitro blue tetrazolium chloride (BCIP/NBT) was successfully used as a chromogenic phosphatase substrate for the detection of alkaline phosphatase labeled probes (with better results than BM-purple, for example). The automating of the whole mount ISH on an Intavis pro device increased the output and replicability of the technique (detailed protocols provided in Fierro-Constaín et al. 2021).

\subsubsection{FLUORESCENT IMMUNOLOCALIZATION}

Fluorescent immunolocalization (IF) can be performed either on paraffin sections of adults and buds (unpublished data) or on whole mount on buds thanks to their transparency
(Rocher et al. 2020) (Table 5.2). Unsurprisingly, the use of paraffin sections not only takes much longer to achieve but also can result in losing antigenic reactivity, as often observed in other tissues (Krenacs et al. 2010); for this reason, most IF experiments are performed on whole mounted buds or juveniles. The IF protocol used in $O$. lobularis buds is a classical one (Rocher et al. 2020; detailed protocol provided in Borchiellini et al. 2021). Nevertheless, the main difficulty faced is the divergence of sponge antigen sequences relative to vertebrate antigens. Most commercialized antibodies, designed against vertebrate proteins, are therefore unusable, except for highly conserved proteins. For instance, we successfully used antibodies against alpha-tubulin (Sigma) and acetylated alpha-tubulin (Sigma), phospho-histone H3 (Abcam) (Rocher et al. 2020). For other proteins, specific antibodies were raised against peptides of interest, for example, against type IV collagen (Rocher et al. 2020; Vernale et al. in press); other specific antibodies are currently under testing.

\subsubsection{Cell Viability, Cell Apoptosis and Cell Proliferation Assays}

During the study of morphogenetic processes or for ecotoxicological purposes, being able to measure and compare cell viability and cell activity can be useful.

Cell viability/death can be estimated very quickly (a couple of minutes) in O. lobularis (Table 5.2), on both dissociated cells (see next sections) or whole buds, by using propidium iodide (PI) staining on dead cell nuclei in orange and fluorescein diacetate (FA) staining on live cell cytoplasm

\section{TABLE 5.2}

\section{Tools for Cellular and Molecular Analyses Available in Oscarella Iobularis}

\begin{tabular}{|c|c|c|}
\hline Resources/Techniques & Availability in $\mathrm{O}$. lobularis & References \\
\hline Transcriptome & $\mathrm{X}$ & For review Renard et al. (2018) \\
\hline Mitochondrial genome & $\mathrm{X}$ & Gazave et al. (2010) \\
\hline Genome & IP* & Belahbib et al. (2018), Renard et al. (2018) \\
\hline Single-cell transcriptome & $\mathrm{IP}^{*}$ & \\
\hline PCR, real-time PCR & $\mathrm{X}$ & Gazave et al. (2008, 2010, 2013), Fierro-Constaín et al. (2017) \\
\hline In situ hybridization & $\mathrm{X}$ & $\begin{array}{c}\text { Gazave et al. (2008), Lapébie et al. (2009), Fierro-Constaín et al. (2017), } \\
\text { Fierro-Constaín et al. (2021) }\end{array}$ \\
\hline Section 1.01 Immunolocalization & $\mathrm{X}$ & Boute et al. (1996), Rocher et al. (2020) \\
\hline RNA interference & & Rocher et al. (2020) \\
\hline Morpholino & & Rocher et al. (2020) \\
\hline Plasmid expression & & Rocher et al. (2020) \\
\hline Pharmacological approach & $\mathrm{X}$ & Lapébie et al. (2009) \\
\hline Cell proliferation assays & $\mathrm{X}$ & Ereskovsky et al. (2015), Rocher et al. (2020) \\
\hline Cell death assays & $\mathrm{X}$ & Rocher et al. (2020) \\
\hline Cell staining methods & $\mathrm{X}$ & Ereskovsky et al. (2015), Rocher et al. (2020), Borchiellini et al. (2021) \\
\hline Wound healing & $\mathrm{X}$ & Ereskovsky et al. (2015), Rocher et al. (2020) \\
\hline Regeneration & $\mathrm{X}$ & Rocher et al. (2020) \\
\hline Cell dissociation/reaggreagation & $\mathrm{X}$ & Rocher et al. (2020), Vernale et al. (in press) \\
\hline
\end{tabular}

\footnotetext{
$* \mathrm{IP}=$ in progress
} 
in green, following Sipkema's protocol (Rocher et al. 2020; Sipkema et al. 2004). As for other sponges, Trypan blue assays were not successful.

TUNEL is a classical method for detecting DNA fragmentation, used to quantify apoptotic cells, and EdU technology is also a classical way to estimate the rate of DNA synthesis (Gorczyca et al. 1992; Salic and Mitchison 2008). Both methods are now mastered on buds of $O$. lobularis, and EdU assays were also performed successfully on adult sections during wound healing and on buds of different stages (Ereskovsky et al. 2015; Rocher et al. 2020; detailed protocol in Borchiellini et al. 2021). EdU provides more readable information than antibodies against Phospho-histone H3 to estimate cell proliferation because of the low rate of cell division at that stage.

\subsubsection{Cell Staining and Tracking}

All embryogenetic and morphogenetic processes in $O$. lobularis were so far described on fixed samples and therefore on the interpretation of static pictures (Boury-Esnault et al. 2003; Ereskovsky and Boury-Esnault 2002; Ereskovsky et al. 2007; Ereskovsky et al. 2013a; Ereskovsky et al. 2015; Rocher et al. 2020). As mentioned in Section 5.4, this type of description results in an incomplete understanding of events occurring during the time course of the morphogenetic process. Therefore, means to stain and track cells are now under development (Table 5.2). Buds, again, because of their abundance and transparency, are suitable to test such techniques. In order to monitor epithelial morphogenesis, means to stain and track choanocytes (choanoderm epithelium) and pinacocytes (exo- and endopinacoderm epithelia) have been the subject of research. Choanocytes can be efficiently and specifically stained by using lipidic markers (CM-DiI dye), by labeled lectins (PhaE, Gsl 1 for instance) or by using their capacity of particle phagocytosis (Indian ink or fluorescent microbeads) (Ereskovsky et al. 2015; Rocher et al. 2020). Because these are non-toxic staining methods, they allow cell tracking along the time course of the process for several hours or days (Indian ink and lectins allow cell tracking after up to five days) (Ereskovsky et al. 2015; Rocher et al. 2020; Vernale et al. in press). A short incubation with wheat germ agglutinin (WGA) was also used to stain exo- and endopinacocytes (Rocher et al. 2020). Unfortunately, at present, no staining methods are available to stain embryo blastomeres or bud mesohylar cells. Because of pigmentation, an adult is much less suitable to perform live cell staining and tracking.

\subsubsection{LosS-OF-FunCtion Approaches}

Loss-of-function (LOF) approaches are required to study gene functions (Weiss et al. 2007; Zimmer et al. 2019). The first way to interact with gene functions was to use pharmacological approaches via small-molecule inhibition, but more recently, other knockdown (morpholino- and RNAimediated methods) and knockout (TALEN- and CRISPR/ Cas9-mediated methods) techniques have been developed and are used successfully in various model organisms. Among Porifera, both pharmacological and RNAi techniques are so far mastered in the demosponge Ephydatia muellieri only (Hall et al. 2019; Rivera et al. 2011; Rivera et al. 2013; Schenkelaars et al. 2016b; Schippers et al. 2018; Windsor Reid and Leys 2010; Windsor Reid et al. 2018; http://edenrcn.com/protocols/\#invertebrate), and a CrisprCas12 approach is recently developed in Geodia (Hesp et al. 2020). In Oscarella lobularis, pharmacological approaches were performed successfully and allowed to interfere with WNT signaling (Table 5.2). This approach showed that WNT signaling is involved in epithelial morphogenetic processes in $O$. lobularis, as is the case in other animals (Lapébie et al. 2009).

More recently, siRNA and morpholino molecules were efficiently transfected into choanocytes (Rocher et al. 2020). Nevertheless, to date, there is neither evidence of interference efficiency (with transcription and transduction, respectively) nor of phenotypic effect. This is presently the main challenging objective $O$. lobularis must reach to become a bona fide model organism, as is also the case for the famous marine demosponge Amphimedon queenslandica.

\subsection{CHALLENGING QUESTIONS BOTH IN ACADEMIC AND APPLIED RESEARCH}

\subsubsection{Finding New Bioactive Secondary Metabolites}

The pharmaceutical research field is still searching for new natural drug candidates. Among marine organisms, marine sponges represent one of the most important sources of diverse natural chemicals with potential therapeutic properties (Ancheeva et al. 2017; Genta-Jouve and Thomas 2012; Rane et al. 2014; Santhanam et al. 2018; Zhang et al. 2017). Indeed, most sponge species synthesize secondary metabolites, and this is interpreted to play a major role in these sessile animals as chemical defense against predators, overgrowth by other organisms and competition for space (Proksch 1994). Studies aiming to characterize these natural compounds therefore represent one of the main domains of applied research performed on sponges. Oscarellidae species have received less attention for this purpose until recently (Ivanišević et al. 2011). Among them, Oscarella species, in particular $O$. lobularis, display a high diversity of apolar compounds (Aiello et al. 1990; Aiello et al. 1991; Cimino et al. 1975; Ivanišević et al. 2011). Oscarella species are the most bioactive species compared to other homoscleromorph sponges: the EC50 values (measured on crude extract effect on the metabolism of the bioluminescent bacterium Vibrio fischeri) range from 36 to $111 \mu \mathrm{g} / \mathrm{mL}(61 \mu \mathrm{g} / \mathrm{mL}$ for $O$. lobularis). The authors suggest a correlation between the secondary metabolite diversity and the estimated bioactivity (Ivanišević et al. 2011). Lysophospholipids (lyso-PAF and LPE C20:2) are the major metabolites identified in O. lobularis (also found in its sister species $O$. tuberculata) (Aiello et al. 1990; Aiello et al. 1991; Cimino et al. 1975; Ivanišević et al. 2011). The origins (from sponge cells or bacterial cells) 
of these compounds and their individual bioactive properties have not been characterized yet.

\subsubsection{Understanding Host-Symbiont InTERACtions}

Thanks to molecular techniques, the microbial community of Oscarella lobularis is now well described (Gloeckner et al. 2013; Jourda et al. 2015). It has been described that (at least part of) this microbiont is vertically inherited (from parent to offspring) both during sexual and asexual reproduction (Boury-Esnault et al. 2003; Ereskovsky and BouryEsnault 2002; Ereskovsky and Tokina 2007; Ereskovsky et al. 2007). But, as for many sponges, the exact nature and mutual benefits of this biotic association are not determined yet and for now remain hypothetical. Because of recent findings on the variation of the bacterial community during the life cycle in other sponges (Fieth et al. 2016), of potential metabolic complementarity between bacteria and the sponge host (Gauthier et al. 2016), evidence of bacteriasponge horizontal gene transfers (Conaco et al. 2016) and now that metagenomic data are acquired for $O$. lobularis, we should take advantage of these data to explore by experimental approaches the ecological and physiological roles of these associations (resource partitioning/supplying between bacteria and sponge host) but also the potential impact of the microbial community on the developmental processes of the sponge as recently observed in marine cnidarians (Tivey et al. 2020; Ueda et al. 2016).

\subsubsection{Deciphering the Origin and Evolution of Metazoan Epithelia}

Epithelia are considered one of the four fundamental tissue types of animals (Edelblum and Turner 2015; Lowe and Anderson 2015; Yathish and Grace 2018). Epithelia cover body surfaces, organs and internal cavities, and they are essential for controlling permeability and selective exchanges between internal and external environments and between the different compartments of a body. Epithelia are patterned at the end of cleavage during embryological development (Gilbert and Barresi 2018; Tyler 2003) (see Section 5.4).

Epithelia are layers of cells defined by three main histological features, according to what is observed in bilaterians: cell polarity, lateral junctions and a basal lamina made of collagen IV (Edelblum and Turner 2015; Lowe and Anderson 2015; Tyler 2003; Renard et al. 2021). Until 1996 (Boute et al. 1996), no sponge species were known to possess all three features; sponges were therefore considered devoid of epithelia. Among sponges, Hexactinellida do not have cell layers but syncytia instead; Demospongiae and Calcarea have cell layers with cell polarity, atypical cell junctions but no basement membrane; in contrast, Homoscleromorpha possess clear cell polarity, unequivocal adherens-like junctions and obvious basement membrane. Whereas the cell layers of demosponges have similar mechanical and physiological properties like bilaterian epithelia, the epithelia of homoscleromorph sponges are the only ones that present similar histological features compared to bilaterians (Ereskovsky 2010; Ereskovsky et al. 2009b; Leys and Hill 2012; Leys and Riesgo 2012; Leys et al. 2009; Renard et al. 2021). For a while, this "true epithelium" was interpreted as a synapomorphy of Homoscleromorpha and Eumetazoa (Borchiellini et al. 2001; Sperling et al. 2007) and suggested the inclusion of Homoscleromorpha in the Epitheliozoa lineage (a clade combining Eumetazoa and Placozoa) (Sperling et al. 2009). The monophyly of Porifera, now supported by numerous phylogenomic analyses (Philippe et al. 2009; Pick et al. 2010; Pisani et al. 2015; Redmond et al. 2013; Simion et al. 2017; Thacker et al. 2013; Whelan et al. 2017; Wörheide et al. 2012), means instead that the last common ancestor of Porifera possessed all three classical features of "typical" epithelia and that some of these features were secondarily lost independently in the three other sponge classes.

Interestingly, whether species present all epithelial features or not, all sponge classes possess the same set of epithelial genes involved in the establishment of cell polarity and the composition of adherens junctions (Belahbib et al. 2018; Renard et al. 2018; Riesgo et al. 2014; Renard et al. 2021). Similar inconsistency between gene content and histological features was reported concerning the basal lamina (Fidler et al. 2017). These findings question the homology of epithelial features between sponges and other animals: Is polarity controlled by the same three polarity complexes as in bilaterians (namely Crumbs, Par and Scribble)? Are adherens junctions described in Homoscleromorpha homologous to bilaterian adherens junctions (i.e. composed of classical cadherin and alpha-beta and delta-catenins)? To answer these questions, complementary molecular and biochemical approaches are in progress in both $O$. pearse $i$ and $O$. lobularis and in parallel in demosponges. The first results obtained suggest that the proteins involved in cell-cell and cell-matrix adhesion would be the same in demosponges and homoscleromorphs, in particular vinculin and beta-catenin (Miller et al. 2018; Mitchell and Nichols 2019; Schippers et al. 2018). To date, there is no clear information concerning the eventual implication of classical cadherins in these junctions.

\subsubsection{Sponge Gastrulation and the Origin of Germ Layers}

Despite the true multicellular and metazoan nature of sponges having been elucidated decades ago (reviewed in Schenkelaars et al. 2019), there is a longstanding debate in the spongiologist community on whether sponges gastrulate. Different points of view compete: i) for some authors, multipolar egression leading to the formation of the coeloblastula during embryogenesis marks the onset of polarization and regionalization processes, suggesting it may be similar to gastrulation (Maldonado and Riesgo 2008); ii) others consider that this process differs from gastrulation in that the resulting embryo apparently consists of one uniform cell layer and lacks polarity (Ereskovsky 2010; Ereskovsky and Dondua 2006) and prefer to hypothesize the gastrulation during larval metamorphosis (reviewed in Ereskovsky 2010; 
Ereskovsky et al. 2013b; Lanna 2015; Leys 2004; Wörheide et al. 2012), when an "inversion of germ layers" results in the formation of the aquiferous system. In the last case, the term "inversion" means that external-most larval cells form the internal-most ("gut-like") structures of an adult sponge, namely the aquiferous system.

However, cellular tracking during the larval metamorphosis in Amphimedon queenslandica has shown no relation between larval and juvenile cell layers; the cells of the larvae do not have specification: all larval cell types are capable of transdifferentiating into all juvenile cell types (Nakanishi et al. 2014; Sogabe et al. 2016). This apparent lack of cell layer and fate determination and stability during metamorphosis in this sponge argues for an absence of gastrulation. In this context, the expression of the transcription factor GATA, a highly conserved eumetazoan endomesodermal marker, in the inner layer of $A$. queenslandica embryos, free larvae and juveniles has been interpreted to provide positional information to cells (Nakanishi et al. 2014). In contrast, in Sycon ciliatum, expression of the same marker in embryo/ larva ciliated micromeres (at the origin of adult choanocytes) and in adult choanoderm has given rise to other conclusions (Leininger et al. 2014). Indeed, the authors suggest that the calcareous sponge choanoderm and the bilaterian endoderm are homologous structures and ciliated choanocytes are germ layers. Thus, the origin of gastrulation and germ layers is still controversial (Degnan et al. 2015; Lanna 2015). Yet the resolution of this problem is the key to comparing embryological stages between sponges and other metazoans and to discussing germ layer homology between all animal phyla.

As mentioned in the section on embryology and in the previous section, Oscarella lobularis (like other homoscleromorph) presents clear epithelial characteristics, and all morphogenetic processes (development, regeneration, budding) are based mainly on epithelial morphogenetic movements in contrast to demosponges (Boury-Esnault et al. 2003; Ereskovsky 2010; Ereskovsky and Tokina 2007; Ereskovsky et al. 2007; Ereskovsky et al. 2009b; Ereskovsky et al. 2013a; Ereskovsky et al. 2013b; Ereskovsky et al. 2015). This feature is expected to result in the formation of more stable cell layers during embryogenesis compared to demosponges (Ereskovsky 2010; Lanna 2015). O. lobularis is thus an interesting model to answer questions about the homology of embryonic morphogenesis (gastrulation) and germ layers in animals (Degnan et al. 2015; Lanna 2015). The techniques now available in this sponge species (see Section 5.7 on functional approaches) are highly significant innovations to answer this fundamental question. The main experimental limitation to do so is the difficult and limited access to embryos and larvae in this species, as sexual reproduction cannot be triggered in aquaria.

\section{ACKNOWLEDGMENTS}

The authors thank all those whose involvement made the development of this emerging model possible: Nicole BouryEsnault and Jean Vacelet for their help in launching our studies on this species; our PhD students Pascal Lapébie, Eve Gazave, Quentin Schenkelaars, Laura Fierro-Constain, Amélie Vernale and Kassandra de Pao Mendonca; the numerous internship students who helped in performing preliminary experiments; the imaging facilities of the France Bioimaging infrastructure; the diving facilities of the Institute OSU Pytheas and divers from the IMBE lab; and the molecular biology and morphology support services of IMBE. We thank Haley Flom for English editing.

The authors acknowledge the Région Sud (Provence Alpes Côte d'Azur), the French Research ministry, the French National Center for Scientific Research (CNRS), Aix-Marseille University and the Excellence Initiative of Aix-Marseille Université-A*MIDEX for providing funds to support our fundamental research, in particular for the funding of the project for international scientific cooperation (PICS) STraS, the A*MIDEX foundation projects ( ${ }^{\circ}$ ANR11-IDEX-0001-02 and AMX-18-INT-021) and the LabEx INFORM (ANR-11-LABX-0054), both funded by the "Investissements d'Avenir" French Government program, managed by the French National Research Agency (ANR). The Russian Science Foundation, Grant n ${ }^{\circ}$ 17-14-01089.

\section{BIBLIOGRAPHY}

Adamska, M. 2016. Sponges as models to study emergence of complex animals. Curr. Opin. Genet. Dev. 39, 21-28.

Adamska, M., Degnan, S. M., Green, K. M., Adamski, M., Craigie, A., Larroux, C. and Degnan, B. M. 2007. Wnt and TGF-beta expression in the sponge Amphimedon queenslandica and the origin of metazoan embryonic patterning. PLoS One 2, e1031.

Adamska, M., Degnan, B. M., Green, K. and Zwafink, C. 2011. What sponges can tell us about the evolution of developmental processes. Zool. Jena Ger. 114, 1-10.

Adamska, M., Larroux, C., Adamski, M., Green, K., Lovas, E., Koop, D., Richards, G. S., Zwafink, C. and Degnan, B. M. 2010. Structure and expression of conserved Wnt pathway components in the demosponge Amphimedon queenslandica. Evol. Dev. 12, 494-518.

Aiello, A., Fattorusso, E., Magno, S., Mayol, L. and Menna, M. 1990. Isolation of two novel $5 \alpha, 6 \alpha$-Epoxy-7-ketosterols from the encrusting demospongia Oscarella lobularis. J. Nat. Prod. 53, 487-491.

Aiello, A., Fattorusso, E., Magno, S. and Menna, M. 1991. Isolation of five new 5 alpha-hydroxy-6-keto-delta 7 sterols from the marine sponge Oscarella lobularis. Steroids 56, 337-340.

Alié, A., Hayashi, T., Sugimura, I., Manuel, M., Sugano, W., Mano, A., Satoh, N., Agata, K. and Funayama, N. 2015. The ancestral gene repertoire of animal stem cells. Proc. Natl. Acad. Sci. U. S. A. 112, E7093-E7100.

Ancheeva, E., El-Neketi, M., Song, W., Lin, W., Daletos, G., Ebrahim, W. and Proksch, P. 2017. Structurally unprecedented metabolites from marine sponges. Curr. Org. Chem. 21, 426-449.

Arendt, D., Musser, J. M., Baker, C. V. H., Bergman, A., Cepko, C., Erwin, D. H., Pavlicev, M., Schlosser, G., Widder, S., Laubichler, M. D., et al. 2016. The origin and evolution of cell types. Nat. Rev. Genet. 17, 744-757.

Babonis, L. S. and Martindale, M. Q. 2017. Phylogenetic evidence for the modular evolution of metazoan signalling pathways. Philos. Trans. R. Soc. B Biol. Sci. 372 (1713), 20150477. 
Belahbib, H., Renard, E., Santini, S., Jourda, C., Claverie, J.-M., Borchiellini, C. and Le Bivic, A. 2018. New genomic data and analyses challenge the traditional vision of animal epithelium evolution. BMC Genomics 19, 393.

Bergquist, P. R. 1978. Sponges. Hutchinson, London; University of California Press, Berkeley \& Los Angeles, CA, 268 pp.

Bergquist, P. R. and Kelly, M. 2004. Taxonomy of some Halisarcida and Homosclerophorida Porifera: Demospongiae from the Indo-Pacific. N. Z. J. Mar. Freshw. Res. 38, 51-66.

Bertolino, M., Cerrano, C., Bavestrello, G., Carella, M., Pansini, M. and Calcinai, B. 2013. Diversity of Porifera in the Mediterranean coralligenous accretions, with description of a new species. ZooKeys, 1-37.

Borchiellini, C., Degnan, S. M., Le Goff, E., Rocher, C., Vernale, A., Baghdiguian, S., Séjourné, N., Marschal, F., Le Bivic, A., Godefroy, N., et al. 2021. Staining and tracking methods for studying sponge cell dynamics. In Developmental Biology of the Sea Urchin and Other Marine Invertebrates: Methods and Protocols, ed. Carroll, D. J. and Stricker, S. A., pp. 81-97. Springer US, New York, NY.

Borchiellini, C., Chombard, C., Manuel, M., Alivon, E., Vacelet, J. and Boury-Esnault, N. 2004. Molecular phylogeny of Demospongiae: Implications for classification and scenarios of character evolution. Mol. Phylogenet. Evol. 32, 823-837.

Borchiellini, C., Manuel, M., Alivon, E., Boury-Esnault, N., Vacelet, J. and Parco, Y. L. 2001. Sponge paraphyly and the origin of Metazoa. J. Evol. Biol. 14, 171-179.

Borisenko, I. E., Adamski, M., Ereskovsky, A. and Adamska, M. 2016. Surprisingly rich repertoire of Wnt genes in the demosponge Halisarca dujardini. BMC Evol. Biol. 16, 123.

Borisenko, I. E., Adamska, M., Tokina, D. B. and Ereskovsky, A. V. 2015. Transdifferentiation is a driving force of regeneration in Halisarca dujardini Demospongiae, Porifera. PeerJ. 3, e1211.

Boury-Esnault, N., Ereskovsky, A., Bézac, C. and Tokina, D. 2003. Larval development in the Homoscleromorpha Porifera, Demospongiae. Invertebr. Biol. 122, 187-202.

Boury-Esnault, N., Lavrov, D. V., Ruiz, C. A. and Pérez, T. 2013. The integrative taxonomic approach applied to Porifera: A case study of the Homoscleromorpha. Integr. Comp. Biol. 53, 416-427.

Boury-Esnault, N., Sole-Cava, A. M. and Thorpe, J. P. 1992. Genetic and cytological divergence between colour morphs of the Mediterranean sponge Oscarella lobularis Schmidt Porifera, Demospongiae, Oscarellidae. J. Nat. Hist. 26, 271-284.

Boute, N., Exposito, J.-Y., Boury-Esnault, N., Vacelet, J., Noro, N., Miyazaki, K., Yoshizato, K. and Garrone, R. 1996. Type IV collagen in sponges, the missing link in basement membrane ubiquity. Biol. Cell. 88, 37-44.

Brunet, T. and King, N. 2017. The origin of animal multicellularity and cell differentiation. Dev. Cell 43, 124-140.

Brusca, R. C. and Brusca, G. J. 2003. Invertebrates. 2rd ed. Sinauer Associates, Sunderland, MA, USA, 936 pp.

Brusca, R. C., Moore, W. and Shuster, S. M. 2016. Invertebrates. 3rd ed. Sinauer Associates is an imprint of Oxford University Press, Sunderland, MA, USA, 1104 pp.

Cardone, F., Gaino, E. R. and Corriero, G. 2010. The budding process in Tethya citrina Sarà \& Melone Porifera, Demospongiae and the incidence of post-buds in sponge population maintenance. J. Exp. Mar. Biol. Ecol. 389, 93-100.

Carter, H. J. 1876. Descriptions and figures of deep-sea sponges and their spicules, from the Atlantic Ocean, dredged up on board H.M.S. 'Porcupine', chiefly in 1869 (concluded). Ann. Mag. Nat. Hist. 18, 226-240.
Cimino, G., de Stefano, S. and Minale, L. 1975. Long alkyl chains3-substituted pyrrole-2-aldehyde-2-carboxylic acid and methyl ester from the marine sponge Oscarella lobularis. Experientia 31, 1387-1389.

Colgren, J. and Nichols, S. A. 2019. The significance of sponges for comparative studies of developmental evolution. Wiley Interdiscip. Rev. Dev. Biol, e359.

Coll, M., Piroddi, C., Steenbeek, J., Kaschner, K., Lasram, F. B. R., Aguzzi, J., Ballesteros, E., Bianchi, C. N., Corbera, J., Dailianis, T., et al. 2010. The biodiversity of the Mediterranean Sea: Estimates, patterns, and threats. PLoS One 5, e11842.

Conaco, C., Tsoulfas, P., Sakarya, O., Dolan, A., Werren, J. and Kosik, K. S. 2016. Detection of prokaryotic genes in the Amphimedon queenslandica genome. PLoS One 11, e0151092.

Degnan, B. M., Adamska, M., Richards, G. S., Larroux, C., Leininger, S., Bergum, B., Calcino, A., Taylor, K., Nakanishi, N. and Degnan, S. M. 2015. Porifera. In Evolutionary Developmental Biology of Invertebrates 1: Introduction, NonBilateria, Acoelomorpha, Xenoturbellida, Chaetognatha, ed. Wanninger, A., pp. 65-106. Springer, Vienna.

Dendy, A. 1905. Report on the sponges collected by Professor Herdman, at Ceylon, in 1902. In Report to the Government of Ceylon on the Pearl Oyster Fisheries of the Gulf of Manaar, ed. Herdman, W. A., pp. 57-246. Royal Society, London. 3 (Supplement 18).

Devenport, D. 2014. The cell biology of planar cell polarity. J. Cell Biol. 207, 171-179.

De Vos, L., Rützler, K., Boury-Esnault, N., Donadey, C. and Vacelet, J. 1991. Atlas of sponge morphology. Smithson. Inst. Press Wash. Lond., 117 pp.

Domingos, C., Lage, A. and Muricy, G. 2016. Overview of the biodiversity and distribution of the class Homoscleromorpha in the tropical Western Atlantic. J. Mar. Biol. Assoc. U. K. 96, 379-389.

Dunn, C. W., Leys, S. P. and Haddock, S. H. D. 2015. The hidden biology of sponges and ctenophores. Trends Ecol. Evol. 30, 282-291.

Edelblum, K. L. and Turner, J. R. 2015. Chapter 12: Epithelial cells: Structure, transport, and barrier function. In Mucosal Immunology. 4th ed., ed. Mestecky, J., Strober, W., Russell, M. W., Kelsall, B. L., Cheroutre, H. and Lambrecht, B. N., pp. 187-210. Academic Press, Boston.

Ereskovsky, A. V. 2006. A new species of Oscarella Demospongiae: Plakinidae from the Western Sea of Japan. Zootaxa 1376, 37-51.

Ereskovsky, A. V. 2010. The Comparative Embryology of Sponges. Springer-Verlag, Dordrecht Heidelberg, London and New York, 329 pp.

Ereskovsky, A. V., Borchiellini, C., Gazave, E., Ivanisevic, J., Lapébie, P., Pérez, T., Renard, E. and Vacelet, J. 2009b. The Homoscleromorph sponge Oscarella lobularis, a promising sponge model in evolutionary and developmental biology. BioEssays 31, 89-97.

Ereskovsky, A. V., Borisenko, I. E., Lapébie, P., Gazave, E., Tokina, D. B. and Borchiellini, C. 2015. Oscarella lobularis Homoscleromorpha, Porifera Regeneration: Epithelial morphogenesis and metaplasia. PLoS One 108: e0134566.

Ereskovsky, A. V. and Boury-Esnault, N. 2002. Cleavage pattern in Oscarella species Porifera, Demospongiae, Homoscleromorpha: Transmission of maternal cells and symbiotic bacteria. J. Nat. Hist. 36, 1761-1775.

Ereskovsky, A. V., Dubois, M., Ivanišević, J., Gazave, E., Lapebie, P., Tokina, D. and Pérez, T. 2013a. Pluri-annual study of 
the reproduction of two Mediterranean Oscarella species Porifera, Homoscleromorpha: Cycle, sex-ratio, reproductive effort and phenology. Mar. Biol. 160, 423-438.

Ereskovsky, A. V., Geronimo, A. and Pérez, T. 2017a. Asexual and puzzling sexual reproduction of the Mediterranean sponge Haliclona fulva Demospongiae: Life cycle and cytological structures. Invertebr. Biol. 136, 403-421.

Ereskovsky, A. V. and Dondua, A. K. 2006. The problem of germ layers in sponges Porifera and some issues concerning early metazoan evolution. Zool. Anz.: J. Comp. Zool. 245, 65-76.

Ereskovsky, A. V., Konyukov, P. Yu. and Tokina, D. B. 2010. Morphogenesis accompanying larval metamorphosis in Plakina trilopha Porifera, Homoscleromorpha. Zoomorphology 129, 21-31.

Ereskovsky, A. V., Lavrov, D. V. and Willenz, P. 2014. Five new species of Homoscleromorpha Porifera from the Caribbean Sea and re-description of Plakina jamaicensis. J. Mar. Biol. Assoc. U. K. 94, 285-307.

Ereskovsky, A. V., Renard, E. and Borchiellini, C. 2013b. Cellular and molecular processes leading to embryo formation in sponges: Evidences for high conservation of processes throughout animal evolution. Dev. Genes Evol. 223, 5-22.

Ereskovsky, A. V., Richter, D. J., Lavrov, D. V., Schippers, K. J. and Nichols, S. A. 2017b. Transcriptome sequencing and delimitation of sympatric Oscarella species $O$. carmela and O. pearsei sp. nov from California, USA. PLoS One 129, $\mathrm{e} 0183002$.

Ereskovsky, A. V., Sanamyan, K. and Vishnyakov, E. 2009a. A new species of the genus Oscarella Porifera: Homosclerophorida: Plakinidae from the North-West Pacific. Cah. Biol. Mar. 50, 369-381.

Ereskovsky, A. V. and Tokina, D. B. 2007. Asexual reproduction in homoscleromorph sponges Porifera; Homoscleromorpha. Mar. Biol. 151, 425-434.

Ereskovsky, A. V., Tokina, D. B., Bézac, C. and BouryEsnault, N. 2007. Metamorphosis of cinctoblastula larvae Homoscleromorpha, Porifera. J. Morphol. 268, 518-528.

Fell, P. 1993. Porifera. In Asexual Propagation and Reproductive Strategies, eds. Adiyodi, K. G. and Adiyodi, R. G., pp. 1-44. Oxford and IBH, New Delhi.

Fernandez-Valverde, S. L., Calcino, A. D. and Degnan, B. M. 2015. Deep developmental transcriptome sequencing uncovers numerous new genes and enhances gene annotation in the sponge Amphimedon queenslandica. BMC Genomics 16, 387.

Feuda, R., Dohrmann, M., Pett, W., Philippe, H., Rota-Stabelli, O., Lartillot, N., Wörheide, G. and Pisani, D. 2017. Improved modeling of compositional heterogeneity supports sponges as sister to all other animals. Curr. Biol. 18, 2724, 3864-3870.

Fidler, A. L., Darris, C. E., Chetyrkin, S. V., Pedchenko, V. K., Boudko, S. P., Brown, K. L., Gray Jerome, W., Hudson, J. K., Rokas, A. and Hudson, B. G. 2017. Collagen IV and basement membrane at the evolutionary dawn of metazoan tissues. eLife 18, 6, e24176.

Fierro-Constain, L. 2016. La reproduction chez Oscarella lobularis Porifera-Homoscleromorpha: gènes impliqués et effets de l'environnement. www.theses.fr.

Fierro-Constaín, L., Rocher, C., Marschal, F., Schenkelaars, Q., Séjourné, N., Borchiellini, C. and Renard, E. 2021. In situ hybridization techniques in the homoscleromorph sponge Oscarella lobularis. Methods Mol. Biol. Clifton NJ 2219, 181-194.

Fierro-Constaín, L., Schenkelaars, Q., Gazave, E., Haguenauer, A., Rocher, C., Ereskovsky, A., Borchiellini, C. and Renard, E. 2017. The conservation of the Germline multipotency program, from sponges to vertebrates: A stepping stone to understanding the somatic and germline origins. Genome Biol. Evol. 9, 474-488.

Fieth, R. A., Gauthier, M.-E. A., Bayes, J., Green, K. M. and Degnan, S. M. 2016. Ontogenetic changes in the bacterial symbiont community of the tropical demosponge Amphimedon queenslandica: Metamorphosis is a new beginning. Front. Mar. Sci. 3, 228.

Fortunato, S. A. V., Adamski, M. and Adamska, M. 2015. Comparative analyses of developmental transcription factor repertoires in sponges reveal unexpected complexity of the earliest animals. Mar. Genomics 24 (2), 121-129.

Fortunato, S. A. V., Vervoort, M., Adamski, M. and Adamska, M. 2016. Conservation and divergence of bHLH genes in the calcisponge Sycon ciliatum. EvoDevo 7, 23.

Francis, W. R. and Canfield, D. E. 2020. Very few sites can reshape the inferred phylogenetic tree. PeerJ. 8, e8865.

Francis, W. R., Eitel, M., R. S. V., Adamski, M., Haddock, S. H., Krebs, S., Blum, H., Erpenbeck, D. and Wörheide, G. 2017. The genome of the contractile demosponge Tethya wilhelma and the evolution of metazoan neural signalling pathways. bioRxiv 120998.

Funayama, N. 2013. The stem cell system in demosponges: Suggested involvement of two types of cells: Archeocytes active stem cells and choanocytes food-entrapping flagellated cells. Dev. Genes Evol. 223, 23-38.

Funayama, N. 2018. The cellular and molecular bases of the sponge stem cell systems underlying reproduction, homeostasis and regeneration. Int. J. Dev. Biol. 62, 513-525.

Funayama, N., Nakatsukasa, M., Mohri, K., Masuda, Y. and Agata, K. 2010. Piwi expression in archeocytes and choanocytes in demosponges: Insights into the stem cell system in demosponges. Evol. Dev. 12, 275-287.

Gaino, E., Burlando, B. and Buffa, P. 1986a. The vacuolar cells of Oscarella lobularis Porifera, Demospongiae: Ulatrastructural organization, origin, and function. J. Morphol. 188, 29-37.

Gaino, E., Burlando, B. and Buffa, P. 1986b. Contribution to the study of egg development and derivation in Oscarella lobularis Porifera, Demospongiae. Int. J. Invertebr. Rep. Dev. 9, 59-69.

Gaino, E., Burlando, B., Buffa, P. and Sará, M. 1986c. Ultrastructural study of spermatogenesis in Oscarella lobularis Porifera, Demospongiae. Int. J. Invertebr. Rep. Dev. 10, 297-305.

Garrabou, J. and Zabala, M. 2001. Growth dynamics in four Mediterranean demosponges. Estuar. Coast. Shelf Sci. 52, 293-303.

Gatenby, J. B. 1920. IX.: Further notes on the Oögenesis and fertilization of Grantia compressa. J. R. Microsc. Soc. 40, 277-282.

Gauthier, M.-E. A., Watson, J. R. and Degnan, S. M. 2016. Draft genomes shed light on the dual bacterial symbiosis that dominates the microbiome of the coral reef sponge Amphimedon queenslandica. Front. Mar. Sci. 3, 196.

Gazave, E. 2010. Etude de gène et voie de signalisation impliqués dans les processus morphogénétiques chez Oscarella lobularis: implications potentielles sur la compréhension de l'origine du système nerveux. www.theses.fr.

Gazave, E., Lapébie, P., Ereskovsky, A. V., Vacelet, J., Renard, E., Cárdenas, P. and Borchiellini, C. 2012. No longer Demospongiae: Homoscleromorpha formal nomination as a fourth class of Porifera. Hydrobiologia 687, 3-10.

Gazave, E., Lapébie, P., Renard, E., Bézac, C., Boury-Esnault, N., Vacelet, J., Pérez, T., Manuel, M. and Borchiellini, C. 2008. NK homeobox genes with choanocyte-specific expression in homoscleromorph sponges. Dev. Genes Evol. 218, 479-489. 
Gazave, E., Lapébie, P., Richards, G. S., Brunet, F., Ereskovsky, A. V., Degnan, B. M., Borchiellini, C., Vervoort, M. and Renard, E. 2009. Origin and evolution of the Notch signalling pathway: An overview from eukaryotic genomes. BMC Evol. Biol. 9, 249.

Gazave, E., Lapébie, P., Renard, E., Vacelet, J., Rocher, C., Ereskovsky, A. V., Lavrov, D. V. and Borchiellini, C. 2010. Molecular phylogeny restores the supra-generic subdivision of homoscleromorph sponges Porifera, Homoscleromorpha. PLoS One 512, e14290.

Gazave, E., Guillou, A. and Balavoine, G. 2014. History of a prolific family: The Hes/Hey-related genes of the annelid Platynereis. EvoDevo 5, 29.

Gazave, E., Lavrov, D. V., Cabrol, J., Renard, E., Rocher, C., Vacelet, J., Adamska, M., Borchiellini, C. and Ereskovsky, A. V. 2013. Systematics and molecular phylogeny of the family Oscarellidae Homoscleromorpha with description of two new Oscarella species. PLoS One 8, e63976.

Gazave, E. and Renard, E. 2010. Evolution of Notch Transmembrane Receptors. In $e L S$, p. American Cancer Society.

Genta-Jouve, G. and Thomas, O. P. 2012. Sponge chemical diversity: From biosynthetic pathways to ecological roles. $A d v$. Mar. Biol. 62, 183-230.

Gerçe, B., Schwartz, T., Syldatk, C. and Hausmann, R. 2011. Differences between bacterial communities associated with the surface or tissue of Mediterranean sponge species. Microb. Ecol. 61, 769-782.

Gilbert, S. F. and Barresi, M. J. F. 2018. Developmental Biology. 11th ed. Sinauer Associates, Sunderland, MA, USA.

Gloeckner, V., Hentschel, U., Ereskovsky, A. V. and Schmitt, S. 2013. Unique and species-specific microbial communities in Oscarella lobularis and other Mediterranean Oscarella species Porifera: Homoscleromorpha. Mar. Biol. 160, 781-791.

Gorczyca, W., Bruno, S., Darzynkiewicz, R., Gong, J. and Darzynkiewicz, Z. 1992. DNA strand breaks occurring during apoptosis: Their early in situ detection by the terminal deoxynucleotidyl transferase and nick translation assays and prevention by serine protease inhibitors. Int. J. Oncol. 1, 639-648.

Hall, C., Rodriguez, M., Garcia, J., Posfai, D., DuMez, R., Wictor, E., Quintero, O. A., Hill, M. S., Rivera, A. S. and Hill, A. L. 2019. Secreted frizzled related protein is a target of PaxB and plays a role in aquiferous system development in the freshwater sponge, Ephydatia muelleri. PLoS One 14, e0212005.

Hammel, J. U. and Nickel, M. 2014. A new flow-regulating cell type in the demosponge Tethya wilhelma: Functional cellular anatomy of a leuconoid canal system. PLoS One 9, e113153.

Hanitsch, R. 1890. Third report on the Porifera of the L.M.B.C. district. Proc. Trans. Liverpool Biol. Soc. 4, 192-238.

Hentschel, E. 1909. Tetraxonida. I. Teil. In Die Fauna SüdwestAustraliens. Ergebnisse der Hamburger südwest-australischen Forschungsreise 1905, eds. Michaelsen, W. and Hartmeyer, R., pp. 347-402. Jena: Fischer. 2 (21).

Hesp, K., Flores Alvarez, J. L., Alexandru, A.-M., van der Linden, J., Martens, D. E., Wijffels, R. H. and Pomponi, S. A. 2020. CRISPR/Cas12a-mediated gene editing in Geodia barretti sponge cell culture. Front. Mar. Sci. 7, 599825.

Hill, M. S., Hill, A. L., Lopez, J., Peterson, K. J., Pomponi, S., Diaz, M. C., Thacker, R. W., Adamska, M., Boury-Esnault, N., Cárdenas, P., et al. 2013. Reconstruction of family-level phylogenetic relationships within Demospongiae, Porifera using nuclear encoded housekeeping genes. PLoS One 8, e50437.

Humbert-David, N. and Garrone, R. 1993. A six-armed, tenascinlike protein extracted from the Porifera Oscarella tuberculata Homosclerophorida. Eur. J. Biochem. 216, 255-260.
Ivanišević, J., Thomas, O. P., Lejeusne, C., Chevaldonné, P. and Pérez, T. 2011. Metabolic fingerprinting as an indicator of biodiversity: Towards understanding inter-specific relationships among Homoscleromorpha sponges. Metabolomics 7 , 289-304.

Jenner, R. A. and Wills, M. A. 2007. The choice of model organisms in evo-devo. Nat. Rev. Genet. 8, 311-314.

Jourda, C., Santini, S., Rocher, C., Le Bivic, A. and Claverie, J.-M. 2015. Draft genome sequence of an alphaproteobacterium associated with the Mediterranean sponge Oscarella lobularis. Genome Announc. 3 (5), e00977-15.

Kanska, J. and Frank, U. 2013. New roles for nanos in neural cell fate determination revealed by studies in a cnidarian. J. Cell Sci. 126, 3192-3203.

Kenny, N. J., Francis, W. R., Rivera-Vicéns, R. E., Juravel, K., Mendoza, A. de, Díez-Vives, C., Lister, R., Bezares-Calderon, L., Grombacher, L., Roller, M., et al. 2020. Tracing animal genomic evolution with the chromosomal-level assembly of the freshwater sponge Ephydatia muelleri. bioRxiv Feb 18, 954784

King, N. 2004. The unicellular ancestry of animal development. Dev. Cell 7, 313-325.

Krenacs, L., Krenacs, T., Stelkovics, E. and Raffeld, M. 2010. Heat-induced antigen retrieval for immunohistochemical reactions in routinely processed paraffin sections. In Immunocytochemical Methods and Protocols, eds. Oliver, C. and Jamur, M. C., pp. 103-119. Humana Press, Totowa, NJ.

Labrenz, M., Lawson, P. A., Tindall, B. J. and Hirsch, P. 2009. Roseibaca ekhonensis gen. nov., sp. nov., an alkalitolerant and aerobic bacteriochlorophyll a-producing alphaproteobacterium from hypersaline Ekho Lake. Int. J. Syst. Evol. Microbiol. 59, 1935-1940.

Lage, A., Gerovasileiou, V., Voultsiadou, E. and Muricy, G. 2019. Taxonomy of Plakina Porifera: Homoscleromorpha from Aegean submarine caves, with descriptions of three new species and new characters for the genus. Mar. Biodivers. 49, $727-747$.

Lage, A., Muricy, G., Ruiz, C. and Pérez, T. 2018. New sciaphilic plakinids Porifera, Homoscleromorpha from the CentralWestern Pacific. Zootaxa 4466, 8-38.

Lanna, E. 2015. Evo-devo of non-bilaterian animals. Genet. Mol. Biol. 38, 284-300.

Lapebie, P. 2010. L'origine des morphogenèses épithéliales et leurs implications concernant l'évolution précoce des métazoaires. www.theses.fr.

Lapébie, P., Gazave, E., Ereskovsky, A., Derelle, R., Bézac, C., Renard, E., Houliston, E. and Borchiellini, C. 2009. WNT/ beta-catenin signalling and epithelial patterning in the homoscleromorph sponge Oscarella. PLoS One 4, e5823.

Laundon, D., Larson, B. T., McDonald, K., King, N. and Burkhardt, P. 2019. The architecture of cell differentiation in choanoflagellates and sponge choanocytes. PLoS Biol. 17, e3000226.

Layden, M. J., Röttinger, E., Wolenski, F. S., Gilmore, T. D. and Martindale, M. Q. 2013. Microinjection of mRNA or morpholinos for reverse genetic analysis in the starlet sea anemone, Nematostella vectensis. Nat. Protoc. 8, 924-934.

Leininger, S., Adamski, M., Bergum, B., Guder, C., Liu, J., Laplante, M., Bråte, J., Hoffmann, F., Fortunato, S., Jordal, S., et al. 2014. Developmental gene expression provides clues to relationships between sponge and eumetazoan body plans. Nat. Commun. 5, ncomms4905.

Lendenfeld, R. von. 1887. On the systematic position and classification of sponges. Proc. Zool. Soc. London. 18, 558-662.

Lévi, C. 1956. Etude des Hailsarca de Roscoff. Embryologie et systematique des demosponges. Arch. Zool. Exp. Gen. 93, 1-184. 
Lévi, C. 1973. Systématique de la classe des Demospongiaria Démosponges. Pp. 577-631. In Traité de Zoologie. Anatomie, Systématique, Biologie, ed. Grassé, P.-P. Spongiaires. 3(1), pp. 577-631. Masson et Cie., Paris.

Lévi, C. and Porte, A. 1962. Étude au microscope électronique de l'éponge Oscarella lobularis schmidt et de sa larve amphiblastula. Cah. Biol. Mar. 3, 307-315.

Leys, S. P. 2004. Gastrulation in sponges. Gastrulation Cells Embryo Ed. Stern CD 2004 N. Y. Cold Spring Harb. Lab. Press, 23-31.

Leys, S. P. and Degnan, B. M. 2001. Cytological basis of photoresponsive behavior in a sponge larva. Biol. Bull. 201, 323-338.

Leys, S. P. and Ereskovsky, A. V. 2006. Embryogenesis and larval differentiation in sponges. Can. J. Zool. 84, 262-287.

Leys, S. P. and Hill, A. 2012. The physiology and molecular biology of sponge tissues. In Advanc. Mar. Biol., pp. 1-56.

Leys, S. P., Mah, J. L., McGill, P. R., Hamonic, L., De Leo, F. C. and Kahn, A. S. 2019. Sponge behavior and the chemical basis of responses: A post-genomic view. Integr. Comp. Biol. 59, 751-764.

Leys, S. P., Nichols, S. A. and Adams, E. D. M. 2009. Epithelia and integration in sponges. Integr. Comp. Biol. 49, 167-177.

Leys, S. P. and Riesgo, A. 2012. Epithelia, an evolutionary novelty of metazoans. J. Exp. Zoolog. B Mol. Dev. Evol. 318, 438-447.

Leys, S. P., Yahel, G., Reidenbach, M. A., Tunnicliffe, V., Shavit, U. and Reiswig, H. M. 2011. The sponge pump: The role of current induced flow in the design of the sponge body plan. PLoS One 6, e27787.

Love, A. C. and Yoshida, Y. 2019. Reflections on model organisms in evolutionary developmental biology. Results Probl. Cell Differ. 3-20.

Lowe, J. S. and Anderson, P. G. 2015. Chapter 3: Epithelial cells. In Stevens \& Lowe's Human Histology. 4th ed., ed. Lowe, J. S. and Anderson, P. G., pp. 37-54. Mosby, Philadelphia.

Ludeman, D. A., Reidenbach, M. A. and Leys, S. P. 2017. The energetic cost of filtration by demosponges and their behavioural response to ambient currents. J. Exp. Biol. 220, 995-1007.

Mah, J. L., Christensen-Dalsgaard, K. K. and Leys, S. P. 2014. Choanoflagellate and choanocyte collar-flagellar systems and the assumption of homology. Evol. Dev. 16, 25-37.

Maldonado, M. 2004. Choanoflagellates, choanocytes, and animal multicellularity. Invertebr. Biol. 123, 1-22.

Maldonado, M. and Riesgo, A. 2008. Reproduction in Porifera: A synoptic overview. Treb. Soc. Cat. Biol. 59, 29-49.

Marion, A. F. 1883. Esquisse d'une topographie zoologique du golfe de Marseille. Cayer et cie.

Meewis, H. 1938. Contribution a l'étude de l'embryogenése des Myxospongiae: Halisarca lobularis Schmidt. Arch. Biol. Liege 59, 1-66.

Miller, P. W., Pokutta, S., Mitchell, J. M., Chodaparambil, J. V., Clarke, D. N., Nelson, W. J., Weis, W. I. and Nichols, S. A. 2018. Analysis of a vinculin homolog in a sponge phylum Porifera reveals that vertebrate-like cell adhesions emerged early in animal evolution. J. Biol. Chem. 293, 11674-11686.

Mitchell, J. M. and Nichols, S. A. 2019. Diverse cell junctions with unique molecular composition in tissues of a sponge Porifera. EvoDevo 10, 26.

Muricy, G., Boury-Esnault, N., Bézac, C. and Vacelet, J. 1996. Cytological evidence for cryptic speciation in Mediterranean Oscarella species Porifera, Homoscleromorpha. Can. J. Zool. 74, 881-896.

Muricy, G. and Pearse, J. S. 2004. A new species of Oscarella Demospongiae: Plakinidae from California. Proc. Calif. Acad. Sci. 55, 598-612.
Musser, J. M., Schippers, K. J., Nickel, M., Mizzon, G., Kohn, A. B., Pape, C., Hammel, J. U., Wolf, F., Liang, C., HernándezPlaza, A., et al. 2019. Profiling cellular diversity in sponges informs animal cell type and nervous system evolution. bioRxiv, 758276.

Nakanishi, N., Sogabe, S. and Degnan, B. M. 2014. Evolutionary origin of gastrulation: Insights from sponge development. BMC Biol. 12, 26.

Nichols, S. A., Dirks, W., Pearse, J. S. and King, N. 2006. Early evolution of animal cell signaling and adhesion genes. Proc. Natl. Acad. Sci. U. S. A. 103, 12451-12456.

Nichols, S. A., Roberts, B. W., Richter, D. J., Fairclough, S. R. and King, N. 2012. Origin of metazoan cadherin diversity and the antiquity of the classical cadherin/ $\beta$-catenin complex. Proc. Natl. Acad. Sci. U. S. A. 109, 13046-13051.

Nielsen, C. 2008. Six major steps in animal evolution: Are we derived sponge larvae? Evol. Dev. 10, 241-257.

Pérez, T., Ivanisevic, J., Dubois, M., Pedel, L., Thomas, O. P., Tokina, D. and Ereskovsky, A. V. 2011. Oscarella balibaloi, a new sponge species Homoscleromorpha: Plakinidae from the Western Mediterranean Sea: Cytological description, reproductive cycle and ecology. Mar. Ecol. 32, 174-187.

Pérez, T. and Ruiz, C. 2018. Description of the first Caribbean Oscarellidae Porifera: Homoscleromorpha. Zootaxa 4369, 501-514.

Philippe, H., Derelle, R., Lopez, P., Pick, K., Borchiellini, C., Boury-Esnault, N., Vacelet, J., Renard, E., Houliston, E., Quéinnec, E., et al. 2009. Phylogenomics revives traditional views on deep animal relationships. Curr. Biol. CB 19, 706-712.

Pick, K. S., Philippe, H., Schreiber, F., Erpenbeck, D., Jackson, D. J., Wrede, P., Wiens, M., Alié, A., Morgenstern, B., Manuel, M., et al. 2010. Improved phylogenomic taxon sampling noticeably affects nonbilaterian relationships. Mol. Biol. Evol. 27, 1983-1987.

Pisani, D., Pett, W., Dohrmann, M., Feuda, R., Rota-Stabelli, O., Philippe, H., Lartillot, N. and Wörheide, G. 2015. Genomic data do not support comb jellies as the sister group to all other animals. Proc. Natl. Acad. Sci. U. S. A. 112, 15402-15407.

Pohlner, M., Dlugosch, L., Wemheuer, B., Mills, H., Engelen, B. and Reese, B. K. 2019. The majority of active rhodobacteraceae in marine sediments belong to uncultured genera: A molecular approach to link their distribution to environmental conditions. Front. Microbiol. 10, 659.

Pozdnyakov, I. R., Sokolova, A. M., Ereskovsky, A. V. and Karpov, S. A. 2017. Kinetid structure of choanoflagellates and choanocytes of sponges does not support their close relationship. Protistology 11, 248-264.

Proksch, P. 1994. Defensive roles for secondary metabolites from marine sponges and sponge-feeding nudibranchs. Toxicon 32, 639-655.

Ramos-Vicente, D., Ji, J., Gratacòs-Batlle, E., Gou, G., ReigViader, R., Luís, J., Burguera, D., Navas-Perez, E., GarcíaFernández, J., Fuentes-Prior, P., et al. 2018. Metazoan evolution of glutamate receptors reveals unreported phylogenetic groups and divergent lineage-specific events. eLife 7 , e35774.

Rane, R., Sahu, N., Shah, C. and Karpoormath, R. 2014. Marine bromopyrrole alkaloids: Synthesis and diverse medicinal applications. Curr. Top. Med. Chem. 14, 253-273.

Redmond, N. E., Morrow, C. C., Thacker, R. W., Diaz, M. C., Boury-Esnault, N., Cárdenas, P., Hajdu, E., Lôbo-Hajdu, G., Picton, B. E., Pomponi, S. A., et al. 2013. Phylogeny and systematics of demospongiae in light of new small-subunit ribosomal DNA 18S sequences. Integr. Comp. Biol. 53, 388-415. 
Renard, E., Le Bivic, A. and Borchiellini, C. 2021. Origin and evolution of epithelial cell types. In Origin and Evolution of Metazoan Cell Types. 1st ed., eds. Leys, S. and Hejnol, A. CRC Press, Boca Raton. https://doi.org/10.1201/b21831.

Renard, E., Leys, S. P., Wörheide, G. and Borchiellini, C. 2018. Understanding animal evolution: The added value of sponge transcriptomics and genomics. BioEssays 409, e1700237.

Richards, G. S. and Degnan, B. M. 2009. The dawn of developmental signaling in the metazoa. Cold Spring Harb. Symp. Quant. Biol. 74, 81-90.

Riesgo, A., Farrar, N., Windsor, P. J., Giribet, G. and Leys, S. P. 2014. The analysis of eight transcriptomes from all Poriferan classes reveals surprising genetic complexity in sponges. Mol. Biol. Evol. 31, 1102-1120.

Riisgård, H. U. and Larsen, P. S. 2017. Particle capture mechanisms in suspension-feeding invertebrates. Mar. Ecol. Prog. Ser. 418, 255-293.

Rivera, A. S., Hammel, J. U., Haen, K. M., Danka, E. S., Cieniewicz, B., Winters, I. P., Posfai, D., Wörheide, G., Lavrov, D. V., Knight, S. W., et al. 2011. RNA interference in marine and freshwater sponges: Actin knockdown in Tethya wilhelma and Ephydatia muelleri by ingested dsRNA expressing bacteria. BMC Biotechnol. 11, 67.

Rivera, A. S., Ozturk, N., Fahey, B., Plachetzki, D. C., Degnan, B. M., Sancar, A. and Oakley, T. H. 2012. Blue-light-receptive cryptochrome is expressed in a sponge eye lacking neurons and opsin. J. Exp. Biol. 215, 1278-1286.

Rivera, A. S., Winters, I., Rued, A., Ding, S., Posfai, D., Cieniewicz, B., Cameron, K., Gentile, L. and Hill, A. 2013. The evolution and function of the Pax/Six regulatory network in sponges. Evol. Dev. 15, 186-196.

Rocher, C., Vernale, A., Fierro-Constain, L., Sejourne, N., Chenesseau, S., Marschal, C., Golf, E. L., Dutilleul, M., Matthews, C., Marschal, F., et al. 2020. The buds of Oscarella lobularis Porifera: A new convenient model for sponge cell and developmental biology. bioRxiv June 23, 167296.

Ruiz, C., Muricy, G., Lage, A., Domingos, C., Chenesseau, S. and Pérez, T. 2017. Descriptions of new sponge species and genus, including aspiculate Plakinidae, overturn the Homoscleromorpha classification. Zool. J. Linn. Soc. 179, 707-724.

Ryan, J. F., Pang, K., Schnitzler, C. E., Nguyen, A.-D., Moreland, R. T., Simmons, D. K., Koch, B. J., Francis, W. R., Havlak, P., Smith, S. A., et al. 2013. The genome of the ctenophore Mnemiopsis leidyi and its implications for cell type evolution. Science 13, 3426164, 1242592.

Salic, A. and Mitchison, T. J. 2008. A chemical method for fast and sensitive detection of DNA synthesis in vivo. Proc. Natl. Acad. Sci. 105, 2415-2420.

Santhanam, R., Ramesh, S., Sunilson, A. J., Ramesh, S. and Sunilson, A. J. 2018. Biology and Ecology of Pharmaceutical Marine Sponges. CRC Press. https://doi.org/10.1201/97813 51132473.

Schenkelaars, Q. 2015. Origine et évolution des voies Wnt chez les métazoaires: étude comparée de diverses espèces d'éponges. www.theses.fr.

Schenkelaars, Q., Fierro-Constain, L., Renard, E. and Borchiellini, C. 2016a. Retracing the path of planar cell polarity. BMC Evol. Biol. 16, 69.

Schenkelaars, Q., Fierro-Constain, L., Renard, E., Hill, A. L. and Borchiellini, C. 2015. Insights into Frizzled evolution and new perspectives. Evol. Dev. 17, 160-169.

Schenkelaars, Q., Quintero, O., Hall, C., Fierro-Constain, L., Renard, E., Borchiellini, C. and Hill, A. L. 2016b. ROCK inhibition abolishes the establishment of the aquiferous system in Ephydatia muelleri Porifera, Demospongiae. Dev. Biol. 412, 298-310.

Schenkelaars, Q., Vernale, A., Fierro-Constaín, L., Borchiellini, C. and Renard, E. 2019. A look back over 20 years of evodevo studies on sponges: A challenged view of Urmetazoa. In Evolution, Origin of Life, Concepts and Methods, ed. Pontarotti, P., pp. 135-160. Springer International Publishing, Cham, Switzerland.

Schippers, K. J., Nichols, S. A. and Wittkopp, P. 2018. Evidence of signaling and adhesion roles for $\beta$-catenin in the sponge Ephydatia muelleri. Mol. Biol. Evol. 35, 1407-1421.

Schmidt, O. 1862. Die Spongien des adriatischen Meeres. Wilhelm Engelmann, Leipzig, 88p.

Schmidt, O. 1868. Die Spongien der Küste von Algier. Mit Nachträgen zu den Spongien des Adriatischen Meeres. Wilhelm Engelmann, Leipzig, 44 pp.

Simion, P., Philippe, H., Baurain, D., Jager, M., Richter, D. J., Di Franco, A., Roure, B., Satoh, N., Quéinnec, É., Ereskovsky, A., et al. 2017. A large and consistent phylogenomic dataset supports sponges as the sister group to all other animals. Curr. Biol. CB 27, 958-967.

Simionato, E., Ledent, V., Richards, G., Thomas-Chollier, M., Kerner, P., Coornaert, D., Degnan, B. M. and Vervoort, M. 2007. Origin and diversification of the basic helix-loophelix gene family in metazoans: Insights from comparative genomics. BMC Evol. Biol. 7, 33.

Simpson, T. L. 1984. The Cell Biology of Sponges. Springer-Verlag, New York.

Singh, A. and Thakur, N. L. 2015. Field and laboratory investigations of budding in the tetillid sponge Cinachyrella cavernosa. Invertebr. Biol. 134, 19-30.

Sipkema, D., Snijders, A. P. L., Schroën, C. G. P. H., Osinga, R. and Wijffels, R. H. 2004. The life and death of sponge cells. Biotechnol. Bioeng. 85, 239-247.

Sogabe, S., Hatleberg, W. L., Kocot, K. M., Say, T. E., Stoupin, D., Roper, K. E., Fernandez-Valverde, S. L., Degnan, S. M. and Degnan, B. M. 2019. Pluripotency and the origin of animal multicellularity. Nature 570, 519-522.

Sogabe, S., Nakanishi, N. and Degnan, B. M. 2016. The ontogeny of choanocyte chambers during metamorphosis in the demosponge Amphimedon queenslandica. EvoDevo 7, 6.

Sorokin, D. Y., Tourova, T. P. and Muyzer, G. 2005. Citreicella thiooxidans gen. nov., sp. nov., a novel lithoheterotrophic sulfur-oxidizing bacterium from the Black Sea. Syst. Appl. Microbiol. 28, 679-687.

Sperling, E. A., Pisani, D. and Peterson, K. J. 2007. Poriferan paraphyly and its implications for Precambrian palaeobiology. Geol. Soc. Lond. Spec. Publ. 286, 355-368.

Sperling, E. A., Peterson, K. J. and Pisani, D. 2009. Phylogeneticsignal dissection of nuclear housekeeping genes supports the paraphyly of sponges and the monophyly of Eumetazoa. Mol. Biol. Evol. 26, 2261-2274.

Srivastava, M., Simakov, O., Chapman, J., Fahey, B., Gauthier, M. E. A., Mitros, T., Richards, G. S., Conaco, C., Dacre, M., Hellsten, U., et al. 2010. The Amphimedon queenslandica genome and the evolution of animal complexity. Nature 466, $720-726$.

Stroebel, D. and Paoletti, P. 2020. Architecture and function of NMDA receptors: An evolutionary perspective. J. Physiol. $1-24$.

Thacker, R. W., Hill, A. L., Hill, M. S., Redmond, N. E., Collins, A. G., Morrow, C. C., Spicer, L., Carmack, C. A., Zappe, M. E., Pohlmann, D., et al. 2013. Nearly complete 28S rRNA gene sequences confirm new hypotheses of sponge evolution. Integr. Comp. Biol. 533, 373-387. 
Tivey, T. R., Parkinson, J. E. and Weis, V. M. 2020. Host and symbiont cell cycle coordination is mediated by symbiotic state, nutrition, and partner identity in a model cnidarian-dinoflagellate symbiosis. mBio 112 , e02626-19.

Tyler, S. 2003. Epithelium: The primary building block for Metazoan complexity. Integr. Comp. Biol. 43, 55-63.

Ueda, N., Richards, G. S., Degnan, B. M., Kranz, A., Adamska, M., Croll, R. P. and Degnan, S. M. 2016. An ancient role for nitric oxide in regulating the animal pelagobenthic life cycle: Evidence from a marine sponge. Sci. Rep. 6, 37546.

Vacelet, J. and Boury-Esnault, N. 1995. Carnivorous sponges. Nature 373, 333-335.

Van Soest, R. W. M., Boury-Esnault, N., Hooper, J. N. A., Rützler, K., de Voogd, N. J., Alvarez, B., Hajdu, E., Pisera, A. B., Manconi, R., Schönberg, C., et al. 2021. World Porifera Database. www.marinespecies.org/porifera on yyyy-mm-dd.

Van Soest, R. W. M., de Kluijver, M. J., van Bragt, P. H., Faasse, M., Nijland, R., Beglinger, E. J., de Weerdt, W. H. and de Voogd, N. J. 2007. Sponge invaders in Dutch coastal waters. J. Mar. Biol. Assoc. U. K. (876), 1733-1748.

Vernale, A., Prünster, M. M., Marchianò, F., Debost, H., Brouilly, N., Rocher, C., Massey-Harroche, D., Renard, E., Bivic, A. L., Habermann, B. H., et al. In press. Evolution of mechanisms controlling epithelial morphogenesis across animals: New insights from dissociation - Reaggregation experiments in the sponge Oscarella lobularis. BMC Ecol. Evol.

Vicente, J., Zea, S. and Hill, R. T. 2016. Sponge epizoism in the Caribbean and the discovery of new Plakortis and Haliclona species, and polymorphism of Xestospongia deweerdtae Porifera. Zootaxa 4178, 209-233.

Vishnyakov, A. E. and Ereskovsky, A. V. 2009. Bacterial symbionts as an additional cytological marker for identification of sponges without a skeleton. Mar. Biol. 156, 1625-1632.

Vosmaer, G. C. J. 1884. Porifera. In: Bronn, H.G., Die Klassen und Ordnungen des Thierreichs, Volume II: 65-176, Pl. III, VII-XVIII.
Wallingford, J. B. 2010. Planar cell polarity signaling, cilia and polarized ciliary beating. Curr. Opin. Cell Biol. 22, 597-604.

Wang, X. and Lavrov, D. V. 2007. Mitochondrial genome of the Homoscleromorph Oscarella carmela Porifera, Demospongiae reveals unexpected complexity in the common ancestor of sponges and other animals. Mol. Biol. Evol. 24, 363-373.

Weiss, W. A., Taylor, S. S. and Shokat, K. M. 2007. Recognizing and exploiting differences between RNAi and small-molecule inhibitors. Nat. Chem. Biol. 3, 739-744.

Whelan, N. V., Kocot, K. M., Moroz, T. P., Mukherjee, K., Williams, P., Paulay, G., Moroz, L. L. and Halanych, K. M. 2017. Ctenophore relationships and their placement as the sister group to all other animals. Nat. Ecol. Evol. 1, 1737-1746.

Windsor Reid, P. J. and Leys, S. P. 2010. Wnt signaling and induction in the sponge aquiferous system: Evidence for an ancient origin of the organizer. Evol. Dev. 12, 484-493.

Windsor Reid, P. J., Matveev, E., McClymont, A., Posfai, D., Hill, A. L. and Leys, S. P. 2018. Wnt signaling and polarity in freshwater sponges. BMC Evol. Biol. 18, 12.

Wörheide, G., Dohrmann, M., Erpenbeck, D., Larroux, C., Maldonado, M., Voigt, O., Borchiellini, C. and Lavrov, D. V. 2012. Deep phylogeny and evolution of sponge phylum Porifera. Adv. Mar. Biol. 61, 1-78.

Yathish, R. and Grace, R. 2018. Cell-cell junctions and epithelial differentiation. J. Morphol. Anat. 2, 111.

Zhang, H., Dong, M., Chen, J., Wang, H., Tenney, K. and Crews, P. 2017. Bioactive secondary metabolites from the marine sponge genus agelas. Mar. Drugs 1511, 351.

Zimmer, A. M., Pan, Y. K., Chandrapalan, T., Kwong, R. W. M. and Perry, S. F. 2019. Loss-of-function approaches in comparative physiology: Is there a future for knockdown experiments in the era of genome editing? J. Exp. Biol. 222 (7), jeb175737. 